NBER WORKING PAPER SERIES

ARE GHETTOS GOOD OR BAD?

David M. Cutler

Edward L. Glaeser

Working Paper No. 5163

\author{
NATIONAL BUREAU OF ECONOMIC RESEARCH \\ 1050 Massachusetts Avenue \\ Cambridge, MA 02138 \\ June 1995
}

Cutler thanks the NIA; Glaeser thanks the NSF. We are grateful to Caroline Minter Hoxby for providing us with the topographical data and to Sarah Kent and Jacob Vigdor for superb research assistance. Janet Currie, Denise DiPasquale, John Kain, Larry Katz, Jeff Kling, Steve Levitt, Jim Poterba, Doug Staiger and seminar participants at Harvard, Stanford and the NBER Labor Studies Workshop provided helpful comments. This paper is part of NBER's research programs in Growth and Public Economics. Any opinions expressed are those of the authors and not those of the National Bureau of Economic Research.

() 1995 by David M. Cutler and Edward L. Glaeser. All rights reserved. Short sections of text, not to exceed two paragraphs, may be quoted without explicit permission provided that full credit, including $\odot$ notice, is given to the source. 


\title{
ARE GHETTOS GOOD OR BAD?
}

\begin{abstract}
Theory suggests that spatial separation of racial and ethnic groups can have both positive and negative effects on the economic performance of minorities. Racial segregation may be damaging because it curtails informational connections with the larger community or because concentrations of poverty deter human capital accumulation and encourage crime. Alternatively racial segregation might ensure that minorities have middle-class role models and thus promote good outcomes. We examine the effects of segregation on African-American outcomes in schooling, employment and single parenthood and find that African-Americans in more segregated areas do significantly worse, particularly if they live in central cities. We control for the endogeneity of location choice using instruments based on political factors, topographical features of cities, and residence before adulthood. Some, but never more than $40 \%$ of this effect, stems from lack of role models and large commuting times.
\end{abstract}

David M. Cutler

Department of Economics

Harvard University

Cambridge, MA 02138

and NBER
Edward L. Glaeser

Department of Economics

Harvard University

Cambridge, MA 02138

and NBER 


\section{Introduction}

The spatial concentration of wealth in America is striking. The average income of the richest census tracts is over 25 times larger than the average income of the poorest census tracts. In the city of Detroit, 40 percent of the population is without a high school degree, 47 percent is not in the labor force, median household income is $\$ 21,000$ and 59 people per 100,000 are murdered annually. In the city of Boston, less than 20 percent of the population is without a high school degree, two-thirds of the population is in the labor force, and the median income is $\$ 32,000$. The murder rate is onethird as high. The concentration of poverty seems to cry out for government policy responses. Enterprise zones, empowerment zones, and a variety of government programs since the 1960s have tried to "fix" the problems of ghettos. These programs have almost always assumed that ghettos themselves are in some sense responsible for the poverty that lies within them.

This concentrated poverty is visually striking, but economic theory does not unanimously claim that concentrations of particular groups are harmful. There is indeed a long literature asserting the negative consequences to the poor (and perhaps also to the rich) of separating poor and rich or separating black and white. There is also, however, a long literature (most recently championed by Wilson (1987)) suggesting that racial segregation may have benefits as well as costs. ${ }^{1}$ While Wilson certainly does not support ghettos, he does argue that as segregation diminishes, middle class African-Americans find it easier to move away from the ghettos. The middle class exodus leaves those remaining in the inner city without role models or "social buffers." Other theories suggest that all types of segregation are beneficial, perhaps because segregation protects infant minority industry or segregation creates homogeneous populations with identical tastes for public goods. There is also a wide range of theory that suggests that economic outcomes are not a function of place of residence.

\footnotetext{
${ }^{1}$ In Benabou (1993), agents choose segregated communities, and Benabou argues that this segregation has high social costs, because segregation eliminates spillovers between high human capital agents and low human capital agents. However, in his model, if the spillovers between high human capital agents are more important than spillovers across classes of agents, then segregation can be socially beneficial.
} 
In the face of this theoretical uncertainty, the empirical literature on the effects of segregated poverty on economic outcomes has primarily focused on John Kain's (1968) spatial mismatch hypothesis. The spatial mismatch hypothesis can usefully be divided into strict and weak forms. The strict form says that problems in black employment occur because blacks are "forced" into neighborhoods that are far away from jobs, and resulting information problems and time costs hurt the blacks who live in segregated areas. The weak form of the hypothesis broadly argues that problems in black employment are related to residential segregation. This form of the hypothesis does not specify the mechanism relating segregation to poor outcomes, and does not assume that black mobility is constrained. With unconstrained mobility, we would expect outcomes for equivalent people to be equalized across locations in a single city, so that all minorities regardless of location will be hurt by segregation.

The empirical literature on the spatial mismatch hypothesis typically focuses on the strict form of the hypothesis; this literature tries to establish a statistical connection between where you live, usually within a single city, and what you earn. Holzer (1991), Jenks and Meyer (1990) and Kain (1992) all ably survey this literature and cite studies, ranging from Kain's original paper to Ihlanfeldt and Sjoquist (1990), which imply that ghetto residence is strongly correlated with negative economic outcomes. A parallel literature on neighborhood effects (Crane (1991), Case and Katz (1991), Borjas (1994)) also documents a substantial relation between where people live, who they associate with, and what their life is like.

But despite the large numbers of papers written in this area, there is still a debate on the basic facts. Ellwood (1986) presents substantial evidence suggesting that similar blacks in different neighborhoods within the same city earn similar amounts (but less than whites in the same city); these results attack the strict form of Kain's spatial mismatch hypothesis, although they leave the weak form of the hypothesis untouched. ${ }^{2}$ The weak form of the

2Ellwood's most famous example is his finding of similar outcomes for blacks in Chicago's South Side (a jobless neighborhood) and Chicago's West Side (a neighborhood with jobs). This finding violates the strict form of spatial mismatch, but it would be a necessary outcome of any 
spatial mismatch hypothesis, that there is a general connection between residential segregation and job market outcomes, does seem to represent the current consensus (e.g. Kasarda (1989), Ihlanfeldt and Sjoquist (1990), Massey and Denton (1993), Quigley and O'Regan (1994)); this consensus is primarily based on within-city correlations between poverty and ghetto residence.

There are several problems with these results. A primary issue is the difficulty of interpreting within-city differences in outcomes. These differences may only represent the sorting by ability that is a natural result of differences in housing qualities and public goods across neighborhoods. After all, when we observe rich people living in rich neighborhoods, our first reaction is to interpret this finding solely as the result of common tastes among the rich, not support for a model of positive spillovers from living in a rich area. Likewise, the presence of poor people in poor neighborhoods need not reveal anything about whether ghettos cause poverty.

A second problem with using within-city evidence is that if we assume mobility across neighborhoods, then even if segregation does lead to worse outcomes, within-city comparisons of outcomes may not pick this up. When people are mobile from one part of a city to another, we expect outcomes for similar people to be the same regardless of where they live. Thus, even if ghettoization substantially hurts all minorities, free mobility might still ensure that there are no differences between ghetto and non-ghetto residents.

The direction of causality is another difficulty in connecting ghettos with poor outcomes. If cities where African-American outcomes are exogenously worse have more sorting of people by race, segregation and poor outcomes will be correlated, but the causality will run in the opposite direction. In the existing literature, attempts to determine the causal relation between segregation and outcomes have been weak or non-existent. A final issue is the selection of people across cities. If more able minorities leave cities with more segregation, then it will appear that segregation results in worse outcomes for the minorities remaining in segregated cities.

model where blacks had free mobility between the South Side and the West Side. This finding does not reject the hypothesis that the overall pattern of segregation hurts the entire black population of Chicago. 
This paper attempts to deal with these problems and provide new evidence on the connection between housing segregation and educational, job market and social outcomes. Our empirical strategy is to examine whether outcomes for minorities are better or worse in cities that are more racially segregated. ${ }^{3}$ By examining segregation and outcomes across cities, we avoid the difficulties inherent in within-city comparisons.

Our data set is 20-30 year old individuals from the 1990 Census Public Use Micro Sample (the 1\% PUMS). We find that in racially segregated cities, African-Americans have lower high school graduation rates, are more likely to be idle, earn less income and are more likely to become single mothers. Among our outcome variables, only the likelihood of graduating from college is not a function of segregation. These results are particularly strong when we compare African-Americans with whites in the same cities, and the results are still true when we control for age, race, ethnicity, gender, city size, city median income, city non-white population, and region.

Having documented the relation between segregation and outcomes, we then addresses the issues of causality and of cross-city migration. To infer causality, we instrument for segregation using fiscal and topographical variables that determine the level of segregation but which should not have an independent effect on outcomes. Our first set of instruments are fiscal variables-- the number of separate municipalities and townships (i.e. governmental jurisdictions) within the MSA and the share of local government revenue in the state that comes from intergovernmental sources. The relation between these fiscal variables and the degree of racial segregation is an interesting auxiliary finding of this paper and provides us with convenient and exogenous instruments for the degree of racial segregation. To lessen any fears that these instruments are endogenous, we use fiscal data from 1962. In fact, the correlations between the fiscal variables in 1962 and 1987 are so high (over .98 for the number of governments and .55 for revenue sharing), that for our purposes it seems completely appropriate

\footnotetext{
${ }^{3}$ We use the Taeuber and Taeuber (1965) index of segregation which measures the share of the non-white population which would have to be moved in order to achieve perfect integration.
} 
to treat these variables as exogenous factors. When we instrument with the fiscal variables, we find that segregation adversely affects minority outcomes.

As a second set of instruments for segregation, we use the number of natural barriers (i.e. rivers) in an MSA. The relation between natural barriers and segregation might occur because natural barriers increase the number of governments (which they do) or for other non-governmental reasons. When we instrument with the topographical data, we continue to find large adverse effects of segregation on outcomes.

To address the issue of cross-city mobility, we instrument for segregation using our same fiscal variables for the MSA where the individual lived five years ago. Since one set of our regressions refers to individuals who are 20-24 years old, this procedure involves looking at the place of residence for individuals when they were between the ages of 15 and 19. Our working assumption is that for these minors, place of residence is largely exogenous. While this is not a perfect instrument, as location while growing up may reflect omitted parental characteristics, it should reduce the basic endogeneity problem. ${ }^{4}$ Again, instrumenting with these variables does not change our basic results.

Our overall results-- for education, income and social behavior-- thus support the claim that segregation adversely affects schooling, employment and parenting outcomes, and that the causality runs from segregation to outcomes. None of our instrumental variables results differ significantly from the results found using OLS.

We extend these results by examining various possible explanations of the segregation effect. Our first potential explanation is that segregation is simply capturing the extent to which blacks live in central cities and central cities are troubled areas. While we do find that there are negative effects associated with central city residence, particularly in a segregated MSA, we do not find

\footnotetext{
${ }^{4}$ While the census does not allow us to observe the characteristics of an individual's parents, the census does allow us to create MSA-level measures capturing the education and family structure of the parental cohort (i.e. individuals aged 40-60). We find that controlling for parental variables does not appreciably diminish our results.
} 
that this effect eliminates (or even lessens considerably) the effect of segregation on outcomes.

We also test three explanations of why ghettos may be bad for blacks: segregation works through reducing the exposure of blacks to educated persons, segregation hurts young individuals because their parents were worse role models, and segregation is damaging because it creates more distance between individuals and their jobs (this is the strict form of the spatial mismatch hypothesis). We do, in fact, find evidence for all three hypotheses. However, including measures of all of these effects never reduces the coefficient on segregation by more than $40 \%$. We interpret these results as suggesting that while all of these arguments have merit, segregation has costs for African-Americans that are beyond the costs of any of these effects.

\section{Theories of Ghettos}

To provide a framework for our subsequent work, this section reviews the major theories of why ghettos may be both good and bad.

\subsection{The Costs of Ghettos}

The costs of segregation have been a major theme in much of American social policy over the past 50 years. The landmark court decision Brown $v$. Board of Education, and the later policy of forced schooling integration, stemmed in part from the perceived costs of separating whites and blacks. Schooling integration, which owed much of its intellectual credibility to the Coleman Report (1966), was justified because of the idea that students learn substantially from their peers and spatial separation of black and white students leads to an intellectual isolation of disadvantaged black children.

Kain (1968) emphasizes the sheer physical costs of transportation between non-white communities and white communities. In his view, the jobs are in the white communities. Those African-American workers who want jobs will have to pay for the transport to the white communities. These transport costs will dissuade some workers and impose costs on other workers. The 
testable implication of this hypothesis is that once we have controlled for the distance between African-Americans and jobs in a city, we do not expect the segregation of that city to have an independent effect on outcomes. ${ }^{5}$

Kain also emphasized the intellectual isolation of ghettos, where AfricanAmericans are not only physically separated from jobs (and wealthy, mainstream society), but they are also informationally separated from those jobs and that society as well. ${ }^{6}$ This information separation means that African-Americans may not know what jobs exist, or what the jobs that do exist need in the form of human capital. Ghetto residents may not be able to accurately assess the returns from legal employment. ${ }^{7}$ Informational separation may also deter the development of the types of human capital that come from observing jobs and other workers. ${ }^{8}$ Informational isolation from mainstream society may also mean that people rely more on their peers, and these peer influences may generate drug use, crime and unemployment. ${ }^{9}$

We will test two restricted versions of this hypothesis. The first version suggests that segregation hurts blacks because segregation determines the extent to which blacks are in contact with more educated people of all races, and that racial segregation just proxies for this lack of contact. This version predicts that once we have controlled for the exposure of blacks to educated persons of all races, racial segregation should not be related to outcomes. A second version of the informational hypothesis suggests that informational isolation works primarily through close family connections. Thus, once we

\footnotetext{
${ }^{5}$ If this view is correct, there are no externalities to ghettos, so there is no efficiency rationale for government intervention, and the damage done by ghetto residency must be less than the price of transportation to the job centers. Conceivably, there are externalities that operate through statistical discrimination or white attitudes that might warrant intervention.

${ }^{6}$ Lazear (1995) documents that immigrants in large immigrant communities (perhaps ghettos) are less likely to learn English, either because the incentives are less for them to enter the mainstream community, or because they have less opportunity to imitate English speakers or perhaps less able immigrants have sorted into these communities.

${ }^{7}$ One possible explanation of the high levels of criminal behavior among ghetto residents is that these residents are not accurately weighing the returns from legal and illegal activity.

${ }^{8}$ Glaeser and Maré (1994) emphasized that the urban wage premium comes from quicker learning, perhaps due to imitation, in cities. If the residents of ghettos have no one good to imitate, we can't expect these workers to receive that wage benefits of living in cities.

9 Case and Katz (1992) document the importance of peer effects. Glaeser, Sacerdote and Scheinkman (1994) show that peer influence in crime is more important when outside, particularly parental, authority is weak.
} 
have controlled for parental attributes we should expect to see little independent effect of segregation on the outcomes of children.

Other disadvantages of spatial segregation may work through the public sector. If there are neighborhood-specific public goods, and these goods are paid for locally or provided in part by local actors (e.g. local PTAs), then separation between whites and African-Americans means that AfricanAmericans will be cut off from high quality public goods. Or, if individuals favor redistribution only to those in their immediate area (as in Cutler, Elmendorf, and Zeckhauser, 1993), then separation of races may result in less desire among the wealthy to direct spending to the poor. The debate on state, rather than local, funding of schools (e.g. Serrano $v$. Priest) has been focused on the costs of segregation that work through public goods. Rich, white areas may provide large levels of schooling, police enforcement and other services which are not accessible to poorer black citizens when there is segregation. ${ }^{10}$ This theory predicts that once we have controlled for the level of public services that blacks receive, we should expect to see no further effect of segregation. ${ }^{11}$

\subsection{The Benefits of Ghettoes}

While the bulk of the literature has argued that ghettos have tremendous costs for the African-American community, there is also a literature that suggests that racial segregation can have beneficial effects. This literature has an academic branch (William Julius Wilson is its most prominent member), but it also has deeper roots in the debate on segregation. People who are (at least somewhat) interested in furthering African-American welfare have advocated spatial separation since at least the founding of Liberia in 1847. More recently in the 1920s, Marcus Garvey and the back-to-Africa movement also advocated separation as a boon to the African-American community.

\footnotetext{
${ }^{10}$ In this case, there may not be anything necessarily wrong with segregation from a Pareto perspective, since the only "positive" function of integration in this model is redistribution.

${ }^{11}$ There are also less obvious costs of spatial segregation; for example, if segregation is high, successful African-Americans will not be able to separate themselves from the problems of the poorer neighborhoods.
} 
Voices as varied as Zora Neale Hurston ${ }^{12}$ and the Nation of Islam have advocated separation, not integration, in order to strengthen the AfricanAmerican community.

Wilson's (1987) argument is that decreased racial segregation means increased segregation by education and income. Glazer and Moynihan (1963) also argue that racial segregation can strengthen black communities because it eliminates segregation by income within the black community:

Segregation helped make Harlem alive. ..... Because of the unbroken pattern of segregation, Harlem included everyone in the Negro community-- the old tiny "upper class," the new professionals and white-collar workers, the political leaders just beginning to take over the old political clubs, the artists and entertainers and writers, as well of course as the domestic workers, the laborers and shady characters.

Handlin (1959) argued that when blacks have access to all neighborhoods "the well-to-do become as eager to preserve property values and dissociate themselves from the poor as their white counterparts." Given free residential mobility, successful African-Americans will either join white communities or segregate themselves into small separate communities. This separation may be beneficial to the wealthy who are thus able to shield themselves from any problems of poorer neighbors (as suggested in footnote 12), but this separation may be extremely costly to the poor. The poor become isolated, not only from whites and jobs, but also from any successful role models within their own communities. Without proximity to the more successful members of the African-American community, poor blacks may be unable to learn skills and work habits.

A second argument (also made by Glazer and Moynihan (1963)) is the neighborhood version of the classic infant industry argument in international trade. Those authors argue that the black insurance industry "developed because Negroes found it hard to get insurance from established companies." Spatial segregation (and discrimination generally) means that

${ }^{12}$ Douglas (1995) claims that Hurston, author of Their Eyes Were Watching God, fought schooling integration in 1950s, because Hurston "saw integration as a threat to the survival of an autonomous black culture." 
all services must be provided for African-Americans by African-Americans. This set of services includes professional and entrepreneurial services which may build human capital in the long run. Integration may lead to whites performing those services and African-Americans specializing in jobs with less learning-by-doing and less potential for human capital accumulation. Indeed, Douglas (1995) argues that the increased success and integration of black performers in the 1920s was a disaster for black playwrights and songwriters, because performers who in 1920 were using black-written material, were by 1930 more successful and chose to employ white writers. Sufficient isolation between white and African-American communities may ensure that African-Americans will do a wide variety of jobs, not just low skill jobs.

A third benefit of segregation is the reverse of public goods arguments made earlier. Segregation enables all individuals to consume the bundle of public goods that they want and can afford. Integration means that different individuals must consume the same bundle of goods and that bundle of goods may be far from their preferred set of government services. Segregation may also lessen ethnic tension and violent interracial strife. ${ }^{13}$

Finally, it is possible that too much freedom to move lessens community cohesion. Traditionally, Jewish ghettos were able to enforce discipline (see Wirth (1956)) by threatening miscreants with expulsion from the community. Since segregation was so complete, this punishment was extremely effective. As integration between Jews and Gentiles rose, this threat of expulsion became less effective and the ability to create community discipline decreased (in everything, including donations to charitable institutions). More generally, freedom to migrate and change locations allows any misbehaving citizen to flee his crimes and makes it less likely that an individual will acquire a stake in his community. ${ }^{14}$

${ }^{13}$ DiPasquale and Glaeser (1994) present evidence suggesting that rioting is more likely in areas with ethnic heterogeneity.

14 DiPasquale and Glaeser (1994) also suggest that high levels of mobility relate to the opportunistic behavior of rioting. 


\subsection{A Model 15}

We now formalize some of the preceding discussion. We assume that there are two races (labeled $A$ and $B$ ), where $A$ is the "majority race" and $B$ is the "minority race." Within these two races, there are also assumed to be two levels of skill, ${ }^{16}$ and we label these levels $\mathrm{H}$ and L. Agents can thus fall into four categories $\mathrm{AH}, \mathrm{AL}, \mathrm{BH}$ and $\mathrm{BL}$. There are measure two of workers and there are two neighborhoods each of which contain enough housing for measure one of workers. Workers of all types can move freely between the two neighborhoods (subject to a discrimination cost on the minority for living in the first neighborhood). One consequence of this free mobility is that utility levels will be equalized across neighborhoods, which implies that segregation may have a negative effect on the minority group generally but that this negative effect will not be found by examining intra-urban variation in utility levels.

Earnings (or success generally) are a function of one's own type and the proportion of high skill types in one's neighborhood. 17 There are assumed to be positive spillovers created by high skill agents, e.g. knowledge spillovers or tax payments for local public goods. ${ }^{18}$ We denote earnings for low skilled workers in community k as $W\left(Q_{A H}^{k}+Q_{B H}^{k}\right)$, where $W^{\prime}()>$.0 , and the earnings of high skilled workers in community $\mathrm{k}$ as $\phi W\left(Q_{A H}^{k}+Q_{B H}^{k}\right)$, where $\phi>1.19$ The notation $Q_{i j}^{k}$ refers to the quantity of race $\mathrm{i}$, wealth $\mathrm{j}$ individuals in community $\mathrm{k}$; $Q_{i j}^{T}$ refers to the total quantity of race $\mathrm{i}$, skill $\mathrm{j}$ individuals. We will constrain our attention to the situation where both the total quantity of $B$

\footnotetext{
${ }^{15}$ This model is derived from Benabou (1993) and earlier formalizations of this topic. This section should be viewed as our attempt to set forth the empirical issues in a formal setting rather than as an independent theoretical contribution..

${ }^{16}$ In fact, we mean "skill" to include a whole range of attributes including education, wealth and any other variables that may generate positive spillovers.

17 Simple extensions of the model that would not change any major results could allow for negative spillovers from low skilled workers or even positive spillovers from these workers. Results would not change as long as the positive spillovers for low skilled workers were less than the negative spillovers from high skilled workers.

${ }^{18}$ One possible form of spillover may be the pecuniary externality that comes from capitallabor complementarity. If the wealthy carry capital with them, then their presence may raise the marginal product of labor in their community.

${ }^{19}$ This complementarity between personal skill and neighborhood skill level drives the selection results that we find in the model.
} 
types is less than one (i.e. $1>Q_{B H}^{T}+Q_{B L}^{T}$ ) and the total quantity of $\mathrm{H}$ types is less than one (i.e. $1>Q_{A H}^{T}+Q_{B H}^{T}$ ).

The cost of housing in the first neighborhood is $C$. The cost of housing in the second neighborhood is normalized to zero. $C$ is an endogenous price which will ensure that one half of the population lives in each neighborhood so that everyone is housed and all houses are used.

There is also a discrimination cost paid by Group B individuals who choose to live in the first neighborhood. This cost is a fixed parameter of the city denoted $\mathrm{D}, \mathrm{D} \geq 0$; the discrimination cost in the second neighborhood is again zero. This discrimination cost might represent psychic costs imposed on the minorities from living in the first neighborhood, or the discrimination cost might mean that minorities who try to work in the first neighborhood receive lower wages because of discriminatory employers. Discrimination costs might also work through the government and might reflect that public goods in the first neighborhood are tailored to Group A individuals while public goods in the second neighborhood are tailored to Group B individuals. In that case, moving from the second to the first neighborhood means that Group B individuals replace the public goods that they want with public goods that they don't want. ${ }^{20}$ We are primarily interested in the effect on Group B outcomes as we change the level of discriminatory cost (D); our empirical measure of changing $D$ will be the increased governmental fragmentation that allows different communities to provide different local public goods. ${ }^{21}$ Chart 1 shows the equilibria that exist at different levels of $D$.

${ }^{20}$ An alternative interpretation assumes that all B citizens begin in the second neighborhood and $D$ represents the moving costs of these citizens into the first neighborhood.

${ }^{21}$ Local public goods that are not desired by group B citizens may be the relatively innocent provision of expensive government services to group A citizens in the first neighborhood. Alternatively, undesired local public goods may mean overt governmental racism against group B citizens. 
One equilibrium is total integration where all groups mix completely. Total integration is never an outcome in the model as long as $D>0,22$ but if $D$ equals zero, total integration is a possible equilibrium outcome. Since the two neighborhoods are identical with complete integration, the cost of housing (C) must equal zero. The welfare levels generated in this equilibrium (and in the other equilibria discussed subsequently) are shown in Chart 2. This equilibrium is in fact unstable, but it remains a useful benchmark. ${ }^{23}$

Case 1-- Segregation by Skill, $0 \leq D \leq(\phi-1)\left(W\left(Q_{A H}^{T}+Q_{B H}^{T}\right)-W(0)\right)$

At low levels of $D$, segregation by skill is the only possible stable equilibrium. The housing cost $(\mathrm{C})$ is determined to make the AL types indifferent between the communities which requires that $W\left(Q_{A H}^{T}+Q_{B H}^{T}\right)-C$, the $\mathrm{AL}$ earnings net of housing cost in the first neighborhood, equal W(0), the AL earnings net of housing cost in the second neighborhood. Exactly enough AL agents choose to live in the first community so that $Q_{A H}^{T}+Q_{B H}^{T}+Q_{A L}^{1}=1$. The conditions for this scenario to occur are that $\phi>1, D \geq 0$, and $D \leq(\phi-1)\left(W\left(Q_{A H}^{T}+Q_{B H}^{T}\right)-W(0)\right)$. Since the AL types are indifferent between the neighborhoods and $\phi>1, \mathrm{AH}$ types do not want to live in the second neighborhood. Since the AL types are indifferent between the neighborhoods and $\mathrm{D} \geq 0$, BL types do not want to live in the first neighborhood. The final condition ensures that $\mathrm{BH}$ types do not want to live in the second community.

For changes in $D$ that keep the equilibrium at segregation by skill, higher levels of discrimination will hurt the highly skilled B types, but will not lead to any higher levels of segregation. This equilibrium suggests that empirical attempts to find a within city effect of ghetto residence will find a strong effect

\footnotetext{
${ }^{22}$ No equilibrium with A and B agents of the same skill level living in both neighborhoods can exist if $\mathrm{D}>0$-- the indifference conditions cannot be satisfied for both groups in that case.

${ }^{23}$ The perfect integration outcome is "unstable" in a casual sense that can be formalized with a simple dynamic model, where W(.) is a function of last period's populations. Following Benabou (1993), the integrated outcome is unstable because if one neighborhood acquired a tiny increase in the number of its skilled workers, that neighborhood would become particularly appealing to skilled workers and all skilled workers would come to that neighborhood, driving up housing prices and driving out the unskilled. These arguments have the flavor of the Schelling (1978) tipping model.
} 
of ghetto residence, but this effect will only occur because of the difference of the skills of minorities in different neighborhoods.

Case 2-- Segregation by Race, $D \geq(\phi-1)\left(W\left(Q_{A H}^{T}\right)-W\left(Q_{B H}^{T}\right)\right)$

The housing cost, $\mathrm{C}$, is again determined to make the AL types indifferent between the neighborhoods, which now requires that $W\left(Q_{A H}^{T}\right)-C$ be equal to $W\left(Q_{B H}^{T}\right)$. Exactly enough $\mathrm{AL}$ agents choose to live in the first community so that $Q_{A H}^{T}+Q_{A L}^{1}=1$. This equilibrium requires that $D \geq(\phi-1)\left(W\left(Q_{A H}^{T}\right)-W\left(Q_{B H}^{T}\right)\right)$, so that $\mathrm{BH}$ types do not want to live in the first community. Higher levels of discrimination will neither hurt the Black community, nor will they lead to any higher degrees of segregation. Minorities have already completely segregated themselves to avoid the costs of discrimination. This equilibrium is the only stable equilibrium for high levels of $D$. There exists an interval of $D$ where both segregation by race and segregation by skill exist as stable equilibria in the region and there exists a third, unstable equilibrium, which will be discussed as the extension.

\section{Segregation and Minority Outcomes}

If we consider the effect of increasing segregation on Group B outcomes, one relevant comparison is between the outcomes under segregation by skill (the low D outcome) and segregation by race (the high D outcome). The BL agents always prefer segregation by race to segregation by skill because they have more skilled agents around them when there is segregation by race. The overall gain for group $\mathrm{BH}$ in moving from segregation by skill to segregation by race is $(\phi-1) W\left(Q_{A H}^{T}+Q_{B H}^{T}\right)+W(0)-\phi W\left(Q_{B H}^{T}\right)-D$ which can be either positive or negative depending on parameter values. The condition that determines whether the average outcome in Group B rises as discrimination (D) falls is:

$$
Q_{B H}^{T}\left[(\phi-1) W\left(Q_{A H}^{T}+Q_{B H}^{T}\right)+W(0)-\phi W\left(Q_{B H}^{T}\right)-D\right] \geq Q_{B L}^{T}\left[W\left(Q_{B H}^{T}\right)-W(0)\right] .
$$

This equation compares the possible gains to the skilled minorities from integrating with the majority with the definite losses to the unskilled minorities that come from being deprived of skilled neighbors. The replacement of racial segregation with segregation by skill will aid the 
minority group if the skilled minorities do gain significantly from this transition and if there are large numbers of skilled minorities. ${ }^{24}$

There are cases where segregation by race is preferred by all minorities to segregation by skill, and segregation by race is always preferred by the low skill minorities. This presents something of a puzzle because of the strong belief of much of the literature that segregation by race hurts minorities. We believe that this puzzle occurs because the comparison that most people make is not between segregation by race and segregation by skill, but rather between segregation by race and total integration.

When we examine the relative benefits of segregation by race and total integration, it is obvious that as long as $Q_{A H}^{T} \geq Q_{B H}^{T}$ (the minority has fewer members of the high skilled group) ${ }^{25}$ both $\mathrm{BL}$ and $\mathrm{BH}$ agents prefer total integration to segregation by race. BL agents also prefer total integration if the alternative is segregation by skill. ${ }^{26}$ In fact, the disagreement between Wilson (1987) and the more traditional analysts of segregation seems to occur because Wilson is comparing segregation by race with segregation by skill, and most observers compare segregation by race with total integration.

Extension--Case 3, $(\phi-1)\left(W\left(Q_{A H}^{T}\right)-W\left(Q_{B H}^{T}\right)\right) \leq D \leq(\phi-1)\left(W\left(Q_{A H}^{T}+Q_{B H}^{T}\right)-W(0)\right)$

A third equilibrium occurs in the region of $\mathrm{D}$ values where both segregation by race and segregation by skill equilibria occur. In this third equilibrium both $\mathrm{AL}$ and $\mathrm{BH}$ types are indifferent between two neighborhoods. ${ }^{27}$ This case is particularly interesting because it allows us to consider a situation where

${ }^{24}$ This equation shows the gain to the overall minority community. This gain can be contrasted to the gain to minorities relative to the effect of segregation on whites or the overall effect of segregation on the community as a whole.

${ }^{25}$ This inequality represents minority skill deprivation, which may be a result of long standing discriminatory practices.

$26 \mathrm{BH}$ agents prefer integration to segregation by skill if $W\left(Q_{A H}^{T}+Q_{B H}^{T}\right)-W(0)<$ $\phi\left(W\left(Q_{A H}^{T}+Q_{B H}^{T}\right)-W\left(.5\left(Q_{A H}^{T}+Q_{B H}^{T}\right)\right)\right.$ and $\mathrm{D}=0$.

${ }^{27}$ This equilibrium is also unstable in a casual sense, because in infinitesimal increase in the number of $\mathrm{BH}$ workers in the first neighborhood would induce all $\mathrm{BH}$ workers to move to that neighborhood. More generally, any equilibrium with both skilled and unskilled workers living in two neighborhoods can be shown to be unstable in this manner. This stability argument, in combination with footnote 5 , suggest that the only stable equilibria of the model for $D>0$ are those where only one group, AL, is living in both neighborhoods. 
equivalent minority workers live in both neighborhoods. Now $C$ and $Q_{B H}^{1}$ are jointly determined to satisfy the two equations:

$$
\begin{gathered}
W\left(Q_{A H}^{T}+Q_{B H}^{1}\right)-W\left(Q_{B H}^{T}-Q_{B H}^{1}\right)=C, \text { and } \\
\phi\left(W\left(Q_{A H}^{T}+Q_{B H}^{1}\right)-W\left(Q_{B H}^{T}-Q_{B H}^{1}\right)\right)=C+D .
\end{gathered}
$$

These equations together imply that higher levels of $D$ will lead to higher levels of $Q_{B H}^{1}$, which will necessarily lead to lower levels of BL welfare, and (in fact) $\mathrm{BH}$ welfare must decline with $\mathrm{D}$ as well.

Discrimination acts negatively against minorities as a whole, but as in any model with free mobility, a mechanism exists that makes living in the ghetto area no worse than living in the non-ghetto area (in this case costly discrimination makes the first neighborhood as unappealing as the low skill ghetto). Unless either minority members could not move between neighborhoods so that equalization of utilities is not implied or discrimination (D) is an unobservable cost while $W($.$) is observable, then$ empirical work should not find a difference in outcomes when comparing people of the same skill level who live in and out of ghettos. However, even if utilities are equalized within a city, we should find a negative effect of segregation on city-wide minority outcomes.

\section{Empirical Framework and Data Description}

Most studies of the effects of ghettos on outcomes examine whether minorities in segregated areas do worse than minorities in non-segregated areas (e.g. Ellwood (1986), Kain (1968)). The previous model suggested that there are two major problems using intra-urban variation to find the negative effects of ghettos. The first problem is that the least able minorities may choose to live in the ghetto areas, which implies that estimates of the effects of ghetto residence will overstate the true effect of ghettos unless all worker heterogeneity (observed and unobserved) is controlled for. Following the results of the previous model, the second problem with using intra-urban variation is that when mobility is not constrained across neighborhoods, 
utilities will be equalized across space. ${ }^{28}$ This effect tends to limit the variation in within city outcomes. ${ }^{29}$ For us to observe intra-urban differences either housing choices must be constrained or the discrimination costs of moving out of the ghetto ( $\mathrm{D}$ in the model) must be unobservable while the negative effects of ghetto residence on wages are observable. ${ }^{30}$

Without instruments to deal with intra-urban selection, we are uneasy about accepting these conditions. We therefore eschew intra-urban tests of the effects of ghettos and instead test whether outcomes across cities are affected by the extent of ghettoization. This empirical approach was suggested by the model and it allows for free intra-urban mobility and possible crossneighborhood spillovers. Our basic question is: Do blacks fare worse in more segregated cities?

Even when the question is posed at this level, there are two issues that are critical to this approach. First, our measure of segregation must be exogenous rather than a response to poor outcomes. Second, we need to control for cross-MSA mobility. We discuss both of these issues below; we first present the data.

\section{Data Description-- Primary Variables}

To examine the effects of segregation on outcomes, we first need to define segregation. We use as our primary measure of segregation the racial mix of housing in a Metropolitan Statistical Area (MSA), which we term "housing

\footnotetext{
${ }^{28} \mathrm{~A}$ common argument justifying constrained mobility is that blacks are restricted from entering white neighborhoods. Of course, all-white neighborhoods would not play any role in estimating the effect of segregation on minorities (since there would be no minorities in those neighborhoods) and the limited mobility needed for intra-urban evidence to be usable must occur across neighborhoods with some minority presence, which seems somewhat implausible.

${ }^{29} \mathrm{~A}$ further condition for finding intra-urban differences in outcomes is that spillovers across communities are limited. Spillovers may range from ghetto-bred crime hurting all of the city's citizens, or that low skill acquisition in the ghetto may result in a set of badly trained minorities who then hurt the reputation of their entire racial group due to statistical discrimination.

${ }^{30}$ In this case utilities will still be equalized over space, but we would observe sizable outcome variation over space.
} 
segregation." An MSA is larger than a city; the Boston MSA, for example, has 2.5 million people, but fewer than 1 million live in the city of Boston. ${ }^{31}$

Within each census tract in the city (a census tract is a contiguous group of roughly 3,000 to 4,000 people) we know the number of blacks, and the total population. ${ }^{32}$ A natural measure of equality is how the share of blacks in the census tract compares to the share of non-blacks. ${ }^{33}$ We define housing segregation as:

$$
\text { Housing Segregation }=\frac{1}{2} \sum_{i=1}^{N}\left|\frac{\text { Black }_{i}}{\text { Black }}-\frac{\text { Non }- \text { black }_{i}}{\text { Non }- \text { black }}\right|
$$

where Black $_{\mathrm{i}}$ is the number of blacks in census tract $\mathrm{i}$, Black is the number of blacks in the MSA, and Non-black is the number of non-blacks in census tract $i$, and Non-black is the number of non-blacks in the MSA. If blacks are distributed evenly throughout the MSA, the term in I.I's will be zero for each census tract and thus zero for the MSA as a whole. If blacks and non-blacks never reside in the same census tracts, the measure of housing segregation will be 1 .

Two points about the measure of housing segregation are worth noting. First, although housing segregation is formed from data on census tracts, it is defined for the MSA as a whole. There is thus one value per MSA. Second, because segregation is defined using the share of blacks and non-blacks in each census tract, it should not be correlated with the percent of the MSA that is black. Indeed, the correlation of segregation and the percent black in the MSA is only .006.

\footnotetext{
${ }^{31}$ We used PMSAs rather than CMSAs and generally assumed that there were no spillovers across metropolitan areas.

${ }^{32}$ The average MSA has 135 census tracks.

${ }^{33}$ This measure is commonly referred to as a dissimilarity index, or a Taeuber Index, after Taeuber and Taeuber (1965). The index is popular because it conceptually measures the share of the population that would need to change census tracks for residence to be evenly distributed. We note that this measure of housing segregation does not capture the degree to which heavily black census tracts are contiguous. Massey and Denton (1992) discuss a number of related measures. They generally find different segregation measures to be highly correlated across cities.
} 
We formed measures of housing segregation for the 209 MSAs with at least 100,000 people and at least 10,000 blacks. Having a large population is important to limit the measurement error in the segregation index. Since the micro data we use does not identify all MSAs uniquely and one city was missing the fiscal variables we discuss below, our regressions are based on 204 MSAs. An appendix shows for each city the levels of housing segregation, fiscal variables and the education exposure measure described in Section VI.

The first row of Table 1 shows summary statistics for housing segregation. The average measure of segregation in 1990 is .586 . The level of segregation varies dramatically across MSAs. The least segregated MSA is Jacksonville, North Carolina (.21); the most segregated MSA is Detroit, Michigan (.87). The standard deviation of segregation is .126.

We relate segregation to measures of outcomes for young people. Our outcome data are from the 1 percent micro sample of the 1990 census. We use census data because the samples are large and many MSAs are identified.

The theories of segregation noted above apply most readily to young people; peer influences should be strongest on the young. ${ }^{34}$ Also, the endogeneity problems should be least severe when we are looking at people who have had a short period of adult life in which to chose their place of residence. We thus examine two groups of the population: people aged 20-24 and people aged 2530. The 20-24 age group is most natural for avoiding the problems of MSA choice-- particularly when we instrument with the characteristics of the city that the individual inhabited five years earlier. The older age group is more appropriate for outcomes involving advanced degrees or labor market outcomes. We selected people in these age groups who lived in an MSA in 1990. We eliminated people born in a foreign country, because immigrants should have a particularly large amount of flexibility in their location choice and endogeneity problems should therefore be particularly large for that group. Our resulting sample contains 97,976 people aged $20-24$ and 139,715 people aged 25-30.

\footnotetext{
${ }^{34}$ Glaeser, Sacerdote and Scheinkman (1994) found that across crimes, social interactions are most important in crimes committed by young criminals.
} 
Our outcome measures are of three types. The first is educational outcomes-the probability that a person has graduated from high school and college. Table 2 shows means of these variables in our two age groups. About 85 percent of people have graduated from high school or have a GED. College graduation rates are 12 percent for the younger age group and 25 percent for the older age group. Because college graduation is increasing so rapidly over this age range, we focus less on the probability of college graduation in the younger age group than in the older age group.

The second class of outcomes is work and income. We use two measures here. The first is an indicator variable for whether the person is "idle" or not. We define idleness as neither working nor being enrolled in school. Empirically, most of the variation in idleness across cities occurs because of differences in the rates of employment rather than the rates of school enrollment. Roughly 10 percent of the sample is idle. The second measure of income is the logarithm of earnings, conditional upon the individual working, not being in school and having positive earnings. We adjust earnings for cross-city price differences, using data from the American Chamber of Commerce Research Association. ${ }^{35}$ We omit people in school from the earnings regression, since these people are expected to have low income; we discuss the possible sample selection below. On average, people aged 25-30 earn 50 percent more than those aged 20-24. This differential includes differences in the weeks worked per years, hours per week and the hourly wage; we decompose earnings into these three sources below.

The third measure of outcomes is particular to women-- whether the woman is an unmarried mother. On average, about 15 percent of women are unmarried mothers.

\footnotetext{
${ }^{35} \mathrm{We}$ gathered data on relatives prices across cities for the first quarter of 1990 . Since not all cities have price indices reported for all quarters, we supplemented this data with data from other quarters between 1989 and 1994. This yielded a total of 150 cities. For the remaining cities, we imputed price indices using fitted values of a regression of price indices on the logarithm of city median household income, the logarithm of city population, and region dummy variables. The imputation equation was (with t-statistics in parentheses):

Price Index $=.262^{*} \ln ($ income $)+.24^{*} \ln ($ pop $) ; R 2=.578 ; N=159$.
}

(.061)

(.009) 
In our equations explaining outcomes, we control for several individual characteristics, also detailed in Table 2. The first three characteristics are racial dummy variables for blacks, Asians, and other non-whites. We also include a dummy variable for Hispanics. We make Hispanic origin and race mutually exclusive; anyone who reports being Hispanic is included in that group alone. About 15 percent of the sample is black, 1 percent is Asian, 0.7 percent is other than non-white, and 7 percent is Hispanic. We also include a dummy variable for women (which has a mean of .5). Finally, we include age dummy variables, to control for any within-group differences in average age.

In addition to these individual controls, we also control for three MSA-level characteristics: the logarithm of MSA population, the percent of the population that is black, and the logarithm of MSA median income. ${ }^{36}$ Because these variables may have different effects on blacks than on nonblacks, we interact each of these variables with a dummy for black. Our estimating equation is therefore:

$$
\text { Outcome }=X^{\prime} \beta+\beta_{1} \text { segregation }+\beta_{2} \text { segregation } * \text { black }+\varepsilon
$$

where $X$ is the racial, ethnic, sex and MSA variables noted above. The coefficient $\beta_{1}$ measures the effect of segregation on whites, and $\beta_{2}$ is the differential effect for blacks relative to whites. We focus on the coefficient $\beta_{2}$.

There are several variables that are not included in equation (3.2). We do not include a dummy variable for whether the person lives in the central city, since this may be endogenous with respect to outcomes; we return below to analyze the effect of central city residence. For the same reason, we do not include any information about the demographic composition of the area in the MSA where the individual lives.

One set of variables that we would like to control for is family background -principally education and income of the parents. This information is not available for individuals in the census who do not live at home, so we cannot

\footnotetext{
${ }^{36}$ Median income is adjusted for cross-city price differences in the same way that earnings are adjusted.
} 
include any of this information. ${ }^{37}$ Later we will control for average parental attributes for blacks in the MSA.

\section{Preliminary Evidence on Segregation and Outcomes}

Table 3 shows some preliminary results on the relation between segregation and outcomes. In this table, we divide the sample up into four subgroups: (1) non-blacks in less segregated cities, (2) non-blacks in more segregated cities, (3) blacks in less segregated cities and (4) blacks in more segregated cities. We look at the means of our outcome variables for these groups. More segregated cities are those with segregation levels higher than the mean level of segregation; less segregated cities have less than the mean level of segregation. Our first five columns show the results for people aged 20-24; the second set of five columns show the results for people aged 25-30.

The first column shows that younger blacks in more segregated cities have a $5.9 \%$ lower graduation rate from high school than younger blacks in less segregated cities. Non-blacks have an insignificant .1\% difference in graduation rates, so the total difference-in-difference estimate of the effect of segregation is $6 \%$ (which is significant statistically). This finding is one of our basic results which will reappear in OLS and instrumental variables regressions: blacks in segregated cities graduate less often from high school.

The second column repeats the exercise for college graduates. Here we find an insignificant effect of segregation on college graduation for blacks, but whites in segregated cities are more likely to have graduated from college. The net difference-in-difference estimate is $-3.1 \%$, which again shows a negative effect of segregation on black outcomes.

The third column examines idleness. Segregation increases the percent idle by $7.2 \%$. This effect is driven entirely by differences in the outcomes of the black population. The fourth column shows a significant depressing effect of segregation on earnings, again driven by differences across the black

${ }^{37}$ Quigley and O'Regan (1994) focus on teenagers and are able to get better information on parental attributes. Better information on parents in their work does not eliminate the negative effect of segregation. 
population. The fifth column shows a significant positive effect of segregation on single motherhood.

Columns six through ten show the same results for 25-30 year old individuals. Again all of the effects are significant and all, except for the college graduate effect, are driven by differences in black outcomes between more segregated and less segregated cities. Further, the magnitude of the differential is about the same for the different age groups. These results will be explored in the subsequent tables, but Table 3 shows the basic empirical facts that we will continue to observe.

Of course, Table 3 did not control for any individual characteristics or for other MSA level variables. Table 4 reports our basic OLS estimates of equation (10). In Table 4, we control for individual racial, ethnic, age, and gender characteristics and MSA size, income, and racial structure. We allow the influence of the MSA variables to differ for blacks and non-blacks. All of these controls are included in all of our subsequent regressions. The columns in Table 4 are structured similarly to those in Table 3, with five columns reporting results for 20-24 year old individuals followed by five columns reporting results for 25-30 year old individuals. We estimate a simple linear probability model because of the difficulties in performing instrumental variables for probit models. ${ }^{38}$ The standard errors in all of our regressions have been corrected for correlation between observations within the same MSA.

The first column shows the effect of segregation on the probability of graduating from high school. Non-black individuals who live in more segregated metropolitan areas are unaffected by the level of segregation in the metropolitan area. Black individuals, however, are extremely affected by the level of segregation. A $.126 \%$ rise in the level of segregation (one standard deviation) leads to a $3.8 \%$ decrease in the probability that a $20-24$ year old black will have graduated from high school. This is roughly $15 \%$ of the average dropout rate for blacks.

38 The OLS results do not differ from the probit results (qualitatively) in the non-instrumented case. 
The next column shows the relationship between college graduation and segregation. There is a negative relation for African-Americans between segregation in the MSA and graduation probability, but the magnitude is only one-fifth as large as the effect for high school graduation. Many 20-24 year old individuals are still in college, so the college graduation rate for this group may not be that meaningful. In this column there is a strong positive correlation between city size and college graduation rates for non-blacks, but this correlation is almost entirely eliminated for blacks.

The third column regresses the probability of being idle (not being employed or at school) on segregation and the other variables. Here we find again no relation between segregation and idleness for non-blacks, but for blacks there is an extremely substantial correlation. A one standard deviation increase in the amount of segregation raises the probability of an African-American, 2024 year old, being idle by $4.1 \%$, roughly one-fourth of the base idleness rate. Among the other city characteristics only median income is correlated with idleness.

The fourth column relates the logarithm of earnings (conditional upon working and not being in school) to segregation. In Table 6, we will decompose earnings into weeks per year, hours per week and wages per hour, but here we only examine the overall relation between earnings and segregation. We find a strong relation between earnings and segregation for African-Americans, and no relation between earnings and segregation for non-blacks. A one standard deviation increase in segregation reduces black earnings by roughly $10 \%$.

Since the fourth column is estimated for people aged 20-24, there is a selection problem that occurs because the most able people may still be in school. If blacks in the segregated cities are more likely to be enrolled in school, then this bias is greater for more segregated cities. In this case, this regression will overstate the true effect of segregation. In other unreported OLS regressions, we have found that for 20-24 year olds enrollment is marginally higher for blacks in segregated cities, but in instrumental variables regression we did not find that enrollment was higher for 20-24 year olds. 
The fifth column shows our last dependent variable: single motherhood. In this column, we are interested only in the probability that a woman (again aged 20-24) has a child without a husband present. Black women in more segregated cities are substantially more likely to be a single parent. When we separate out single mothers into widowed, separated and divorced mothers and mothers who have never married, we find that essentially all of the effect comes from changes in the number of mothers who have never married. This connection between segregation and single parenthood suggests that one force that perpetuates ghetto poverty is that ghettos seem to have weaker families.

The sixth through tenth columns repeat the first five columns for the older sample of individuals. The results are qualitatively unchanged, and even quantitatively few of the results are very different. All of the coefficients on the interaction between segregation and race (except for single motherhood regression) have fallen somewhat in magnitude, but all of the coefficients (except for college graduation) retain their significance and remain close to the earlier coefficients. One explanation of the reduction in the coefficients for the older cohort is that this change represents a real effect; older individuals may be less dependent on their neighborhood than younger individuals. Alternatively, the magnitude of the coefficients may be smaller for older cohorts because segregation delays certain outcomes (such as high school or college graduation) but does not eliminate them entirely.

\section{Correcting for Endogeneity}

As discussed earlier, these OLS results may not indicate causality. There are two principal difficulties. First, segregation itself may be the result of poor economic outcomes, rather than a cause of poor outcomes. Second, individuals who choose to live in more segregated cities may be those who are least successful, while those who are more successful may move to less segregated cities.

The first problem can be handled if we have a clean set of instruments for

local segregation. We use two sets of instruments for local segregation. The first set of instruments includes two fiscal variables: the number of 
governments (municipalities and townships) in the MSA and the share of revenue that is not raised at the local level. In theory, the number of local governments increases the gains from sorting geographically in the classic Tiebout (1958) sense. When there is only a single jurisdiction in a metropolitan area, then moving neighborhoods can rarely generate gains from lower taxes or more generous government programs. With multiple jurisdictions, entrepreneurial politicians will offer a variety of services to attract different types of people and individuals will segregate. In the context of the model, different jurisdictions may impose an added cost on blacks trying to change neighborhoods because a different neighborhood may have different public goods and perhaps even public goods designed to discourage racial integration. ${ }^{39}$

This instrument is valid unless the number of governments is itself endogenous. To limit potential endogeneity problems, we use only the number of municipality and township governments. Other governments-school districts, special districts and county governments-- are excluded because they vary over time. In contrast, the number of municipalities and township governments is essentially constant. Indeed, to examine this issue more fully, Figure 1 shows the number of municipality and township governments across MSAs in 1987 and 1962. The number of governments in 1962 is less likely to be a consequence of black outcomes in 1990 than the newer value of government fragmentation. As Figure 1 shows, the correlation between 1962 and 1987 values of the number of governments is over $98 \%$. To avoid any potential endogeneity problems we use the number of governments in 1962 as the instrument, although the strong correlation in the number of governments over time means that our results are almost completely independent of the year of this variable that we use. ${ }^{40}$

\footnotetext{
${ }^{39}$ Examples of racially oriented public goods may be racist policemen or schooling designed particularly for white suburban residents. Differences in governments may also induce skill based segregation (i.e. successful blacks prefer the same government as successful whites), which may lead to racial integration. The effect of number of governments on segregation is ultimately an empirical issue.

${ }^{40}$ The changes generated by switching from the 1962 values that we use to more current values are generally less than $1 / 100$ of the parameter estimate.
} 
Table 1 gives summary statistics for this instrument. The average MSA had 40 separate jurisdictions in 1962, and the number of jurisdictions ranged from 1 to 339 . Since segregation appears most strongly related to the logarithm of the number of governments, we use that variable as our instrument. The relationship between the logarithm of the number of jurisdictions and the amount of housing segregation is shown in Figure 2, and the correlation is reported in the bottom panel of Table 1 . Segregation is significantly higher in areas with more governments.

The second instrument that we use is the percent of local revenue in the state that comes from intergovernmental transfers (i.e. revenues allotted from the state and the federal government). In areas with more intergovernmental transfers, the incentives to segregate should be smaller, and thus segregation should be lower. If intergovernmental transfers for a given city are determined by city-specific black poverty, then the local revenue share will not be exogenous. We believe that using the statewide value of this variable enables it to capture state-specific political characteristics, not city-specific poverty. Again we used the 1962 value of this variable to lesson endogeneity. As Figure 3 shows, the degree of local revenue sharing is generally constant over time; the correlation between the two is years is .55 . In the average city in 1962, $28 \%$ of revenues came from intergovernmental transfers (see Table 1). The relationship between these transfers and racial segregation is shown in Figure 4. In states where more money is transferred between governments, cities on average are less segregated.

The first stage regression of segregation on these two instruments yields the following results ( $t$-statistics are listed in parentheses):

$\begin{array}{ccc}\text { Segregation }=.053^{*} \log (\text { Number of Gov'ts }) & -.219^{*} \text { Transfer Share; } & N=208 \\ (.006) & (.096) & R^{2}=.318\end{array}$

As predicted, segregation is significantly and positively related to the number of governments and segregation is significantly and negatively related to the share of revenue that comes from intergovernmental sources. Since our basic regression specification (3.2) has segregation and its interaction with 
black we instrument for these variable with the two fiscal variables and their interactions with the black dummy.

Our second set of instruments is the number of rivers within and between MSAs. Since rivers divide MSAs into natural subunits, we expect areas with more rivers to have more political boundaries and therefore more segregation. We use the presence of rivers both within and between counties to capture the presence of natural barriers. ${ }^{41}$ The river data are only available for 179 MSAs; these MSAs account for most (over $90 \%$ ) of the population in our sample. ${ }^{42}$ We include quadratic terms in the number of rivers to capture non-linearities in the relationships between rivers and segregation. The first stage regression using this data is:

\section{Segregation $=.033^{*}$ Intercounty River $-.0021^{*}$ Intercounty River ${ }^{2}+$ \\ (.0008)}

$$
\begin{aligned}
& .033^{*} \text { Intracounty River }-.0005^{*} \text { Intracounty River }{ }^{2} ; N=179 \\
& \begin{array}{lll}
(.004) & (.0002) & R^{2}=.198
\end{array}
\end{aligned}
$$

The positive and concave relationship between rivers and segregation suggests that natural boundaries do indeed increase the cost for minorities of moving into white neighborhoods.

While in principle, these barriers could increase segregation through mechanisms other than governmental fragmentation, ${ }^{43}$ we find that when we control for governmental fragmentation rivers have relatively little explanatory power. Thus we conclude that rivers are associated with

\footnotetext{
${ }^{41}$ We are extremely grateful to Caroline Minter Hoxby for the use of these instruments which are described in Hoxby (1985).

${ }^{42}$ The river data are available for CMSAs (Consolidated Metropolitan Statistical Areas), while our segregation and outcome data are grouped by Primary Metropolitan Statistical Areas (PMSAs). This only affects a few areas and should not have a large effect on the results.

${ }^{43}$ Natural barriers could create segregation because natural barriers make it hard for individuals to leave the ghetto and still stay close to their old neighborhood, thus increasing the cost of integrating. Natural barriers might increase differentiation among housing units over space (i.e. one side of a river might be more desirable than another) which in turn might increase segregation by income or race; and natural barriers might provide obvious boundaries that facilitate the exclusion of a minority group from a neighborhood (i.e. racist realtors find it easy to enforce a rule that excludes minorities from one side of a river).
} 
segregation primarily because they increase governmental fragmentation and separate jurisdictions within an MSA make it less likely that integration will occur. Nevertheless, since the number of rivers is surely exogenous to segregation, we present results using this instrument as well. We instrument for segregation and its interaction with race using the four river variables and their interaction with a black dummy variable.

To address the issue of cross-MSA endogeneity, we instrument with the 1962 fiscal characteristics of the MSA where the individual lived five years earlier. Our assumption is that where people lived before they are 18, and even as young adults, is somewhat less endogenous than where they choose to live as adults. Of course, there is still the problem that the MSA chosen early in life may be correlated with omitted parental characteristics. ${ }^{44}$ Nevertheless, using living arrangements before age 19 should lessen the endogeneity somewhat and if this set of instruments does not change the estimates greatly, we become more comfortable believing the endogenous MSA choice is not a significant problem.

Our regressions using previous city of residence are based solely on individuals who lived in MSAs in our sample both in 1990 and in 1985. If there is selection between MSAs and rural areas, this selection would not be dealt with by our results. When we regressed the probability of leaving all MSAs on initial MSA segregation characteristics, however, we found no relationship. This finding suggests that the selection of only those individuals who stayed in MSAs is not decisive.

Tables 5 and 6 present instrumental variables estimates for our outcome equations. These regressions include the full set of demographic and MSA level controls included in Table 4, but for simplicity we report only the coefficients for segregation. The upper panel of Table 5 shows the results using the fiscal instruments for where the individual currently lives. The lower panel shows the results using fiscal instruments for where the

44 While we do not know an individual's parental attributes, we do know the average parental attributes in the MSA. In some sense, this knowledge is enough, since our results are only biased if omitted parental characteristics are correlated with segregation which is an MSA-level variable. We find that including these variables in our regressions does not eliminate our results. 
individual lived five years earlier. The first regression in Table 5 shows the results on high school graduation rates. Our use of instruments for the contemporaneous MSA in panel A increases the magnitude of the coefficient on segregation for African-Americans significantly. In the lower half of the first column, what we call panel B, the segregation interaction with blacks stays significant and systematically segregation hurts black outcomes.

The second column shows the effects of segregation on college graduation rates. The effect of segregation on white college outcomes is significantly positive when we instrument for segregation. The interaction of segregation and race is significantly negative, but the overall effect of segregation on blacks is not significant. The same qualitative results appear using the Panel $B$ instruments. These instrumental variables results suggest that more nonblacks have graduated from college in segregated cities, but that fewer blacks have graduated. The shift between Tables 4 and 5 in the college graduation rate results suggests that segregation may have an effect on college graduation rates (positive for non-blacks and negative for blacks relative to non-blacks), but that mobility eliminates that effect in the OLS regressions.

The third column shows the effect of segregation on idleness. Under both specifications (i.e. panels A and B), segregation increases idleness for blacks and by an amount almost identical to the effect found with OLS. The fourth column shows the effect of segregation on earnings. Both forms of instrumenting increase the magnitude of the negative relation between segregation and earnings for blacks. The fifth column shows the results for single motherhood. In both cases, there are significant positive effects of segregation on single motherhood, although the magnitude is lower when instruments for previous city of residence are used.

Columns 6-10 repeat these results for 25-30 year olds. The results on high school graduation, idleness, earnings and single motherhood are all essentially unchanged from the ordinary least squares results. We find under specification $B$ a negative effect of segregation on college graduation for blacks (as we did for 20-24 year olds), but under specification A, there is no effect of segregation on college graduation. Overall, the results do not change sizably 
from the OLS results in Table 4; segregation adversely affects black outcomes and this finding does not come from cross-city migration of successful people.

These results are robust to a variety of alternative specifications. Most importantly, we have reestimated the equations in Table 5 with MSA fixed effects. Adding fixed effects absorbs the segregation variable for non-blacks as well as the variables for MSA population, median income, and percent black in the city. The interaction terms of each of these variables with the black dummy variable are still identified, however. In the fixed effects specification (which we do not show), the coefficients on the interaction terms are essentially unchanged from those without fixed effects. We also estimated specifications including region dummies; none of our results changed significantly when we controlled for region of residence.

Table 6 reestimates the results again using rivers as instruments. Since using rivers necessitates making our sample somewhat smaller (179 as opposed to 204 MSAs), we have rerun the OLS results for that smaller sample in Panel A of Table 6. None of the results change significantly from the first set of OLS estimates. Panel $B$ reestimates the equations using rivers as instruments. In all of the columns, our basic results are reproduced. Segregation has a negative effect on black outcomes if outcomes are measured by high school graduation rates, idleness, earnings or single motherhood. Moreover, the parameter estimates are qualitatively unchanged from Table 5. Again, the results of Table 6 confirm our result that adverse black outcomes in segregated communities are, in fact, caused by the degree of segregation.

Overall, the instrumental variables results strongly support the OLS results and make us believe that segregation drives poor outcomes, and not the other way around. We find consistently large effects of segregation on earnings, idleness, high school graduation and single motherhood. The results on college graduation are weak although some of the results show a significant college graduation interaction.

While the results in Tables 4,5 and 6 show a significant relation between segregation and earnings for blacks, we did not break this relation down into its various components. In addition, these effects did not control for the 
schooling level of the individuals. In Table 7, we decompose earnings into its components using the fiscal variables as instruments, and we control for education.

The first two columns show the effect of segregation on the decision to work and earnings conditional on working. In both cases, segregation is negatively associated with outcomes. The effect of segregation on earnings (conditional on working and not being in school) is smaller than the effect shown in the ninth column of Table 5, because now we have controlled for education. Since segregation affects earnings in part through lowering education, by controlling for education we eliminate a portion of the effect of segregation on earnings. Still, even controlling for education, segregation is negatively related to earnings.

To evaluate the magnitude of these two effects, we note that:

$$
\begin{aligned}
& \frac{\partial \text { Earnings }}{\partial \text { Segregation }}=\frac{\partial[\text { E(Earnings } \mid \text { Working }) \operatorname{Pr}(\text { Working })]}{\partial \text { Segregation }}= \\
& \operatorname{Pr}(\text { Working }) \frac{\partial E(\text { Earnings } \mid \text { Working })}{\partial \text { Segregation }}+E(\text { Earnings } \mid \text { Working }) \frac{\partial \operatorname{Pr}(\text { Working })}{\partial \text { Segregation }}
\end{aligned}
$$

where $\operatorname{Pr}(X)$ indicates the probability of $X$ occurring and $E(A \mid X)$ indicates the expectation of $A$ conditional upon $X$ occurring. When we perform this decomposition we find that over $85 \%$ of the effect of segregation on earnings comes through the probability of work and less than $15 \%$ comes from earnings while working. 45

The next three columns perform a further decomposition of earnings conditional upon working into weeks worked, hours per week and hourly wage. The lion's share of the earnings result is in weeks worked. There is also a significant effect of segregation on hours per week. There is no significant effect of segregation on the hourly wages. Overall, we conclude that the relation between earnings and segregation works through time spent

\footnotetext{
${ }^{45}$ To make this decomposition operational, we are actually defining earnings as Log(Earnings) and assuming that $\log$ (Earnings) $=0$ when individuals are not working.
} 
working (either having work or the amount of time spent at works) not through the wage while working. ${ }^{46}$

\section{How Does Segregation Affect Outcomes?}

Two-thirds of African-Americans live in central cities, compared with only one-third of non-blacks. Perhaps the differential effect of segregation on African-Americans is really just a differential effect of segregation on central city residents. To test this hypothesis, and to try to examine whether segregation affects different neighborhoods within the same city differently, we augment equation (3.2) to:

$$
\begin{aligned}
& \text { Outcome }=X^{\prime} \beta+\beta_{1} \text { segregation }+\beta_{2} \text { segregation } * \text { black }+\beta_{3} \text { centralcity } * \text { black } \\
& +\beta_{4} \text { segregation } * \text { centralcity }+\gamma^{*} \text { centralcity }+\varepsilon .
\end{aligned}
$$

If segregation is acting through its effect on central city residence, then the coefficient on segregation*centralcity will be negative while the coefficient on segregation*black will be zero. If segregation affects blacks but not whites, the coefficient on segregation*black will be negative and that on segregation*centralcity will be zero.

Just as segregation within a city may be endogenous, central city residence may also be endogenous and OLS estimates of (6.1) may be biased. We instrument for both segregation and central city residence to address this problem. We add to our list of instruments the share of an MSA's land area that is in the central city. As this share increases, the probability that a given person lives in an MSA should increase. The average MSA has $7 \%$ of its acreage in central cities. We have also run first stage regressions for segregation and central city residence and used the predicted values from those first stage regressions as instruments. ${ }^{47}$

\footnotetext{
${ }^{46}$ Our wage effect is conditional upon working. It is possible that the wage in segregated cities (for all workers) is lower and that this lower wage drives weeks worked through labor supply effects.

${ }^{47}$ Denoting the share of land area in the central city as size, the first set of instruments is $\ln ($ gov $), \ln (\text { gov })^{*}$ black, $\ln (\text { gov })^{*}$ size, rev, rev*black, rev*size, size and size*black. In addition, we form predicted values of segregation and central city residence based on the following e qua tions: $\quad$ Segregation $=X^{\prime} \delta+\delta_{1} \ln ($ gov $)+\delta_{2} r e v+\delta_{3} \operatorname{size}+\varepsilon$ a $\mathrm{n} d$
} 
Unfortunately, we do not know central city residence for all of our observations. Data on residence are given by PUMAs-- groups of at least 100,000 people living contiguously. Some PUMAs encompass the whole MSA, and some span both central city and non-central city areas. In neither of these cases do we know if, in fact, the individual lives in the central city. We thus omit observations where central city status is not known with certainty. When we do this, our sample size falls by about one-third.

Table 8 presents the results of estimating equation (6.1) and suggests two broad conclusions. First, the effect of segregation is not just one of central city residence. In essentially all of the equations, blacks fare worse in more segregated areas, even controlling for central city residence and interactions of central city and segregation. In some cases, particularly for the younger age group, segregation has particularly adverse effects on all central city residents although this is not uniformly true.

Second, there is some evidence that location in a central city does lead to worse outcomes. This is particularly true for education and single motherhood in the other group. The coefficients in the other regressions are less clear. Furthermore living in a central city occasionally has a differential impact between blacks and whites, and when there is a differential impact central city residence is worse for blacks than for whites. These results suggest there may be intra-urban differences in outcomes that can be found, but these results are not as consistent across outcome measures as our inter-urban results.

The finding that both race and space matter for at least some adverse outcomes suggests that non-blacks may fare poorly when they live near blacks in more segregated areas. To test this in detail would require separating the segregation*central city variable into an effect for blacks and one for non-

CentralCity $=X^{\prime} \theta+\theta_{1} \ln ($ gov $)+\theta_{2}$ rev $+\theta_{3}$ size $+\theta_{4} \ln ($ gov $) *$ black $+\theta_{5}$ rev $*$ black $+\theta_{6}$ size $*$ black $+\varepsilon$. We include the interactions with black in the second equation because blacks and non-blacks may respond differently to a given number of governments, or the degree of density in the central city. We then form predicted values (denoted pseg and pcc), and add to our instrument set pseg, pseg*black, pseg*pcc, pcc and pcc*black. 
blacks. When we attempted to do this, however, we found it difficult to estimate the separate effects. This is not surprising given that the number of non-central city blacks in a typical city is relatively small, even in our Census sample. Addressing the issue of the "spillovers" between blacks and whites will therefore have to await future research. We can conclude, however, that race is a principal dimension by which segregation affects outcomes, and is not just a proxy for where in the city an individual lives.

\section{Different Theories of Segregation}

A complete analysis of why segregation affects black outcomes is beyond our scope here. Still, it seems valuable to address certain theories in a cursory manner. The preceding results eliminated the view that segregation worked only by making central cities damaging places to live. Race had an independent, and often much larger, connection to the deleterious effects of segregation than did central city location. The next two tables address three alternative hypotheses about why segregation matters.

The first hypothesis is that blacks fare worse than non-blacks because they have less contact with educated people. To test this, we create a measure of the interactions between blacks and those with more education in each MSA. We define educated people as those who attended college for some time, whether or not they obtained a degree. ${ }^{48}$

Consider a black living in census tract $i$. If that person observes the behavior of people predominantly in his or her census tract, the share of educated people that this person observes is the number of educated people in that tract (denoted $\mathrm{Educ}_{\mathrm{i}}$ ) divided by the total number of people in that tract (denoted Persons $\mathrm{s}_{\mathrm{i}}$. ${ }^{49}$ Within an MSA, therefore, we can measure the amount that the average black will encounter educated people of all races:

\footnotetext{
${ }^{48}$ This measure is extremely highly correlated (approximately $90 \%$ ) with a measure capturing interactions with high school graduates.

${ }^{49}$ This number of educated persons and the total number of persons includes only individuals over the age of 25 .
} 


$$
\text { Educated Exposure }=\sum_{i=1}^{N} \frac{\text { Black }_{i}}{\text { Black }_{\text {Persons }}}-\frac{\text { Educ }_{i}}{\text { Persons }_{\text {Per }}}
$$

If all census tracts were racially and educationally equal, the educated share for blacks would be the MSA-wide proportion of educated persons. We subtract this city-wide average from our measure of education exposure, since we do not want to identify our estimates based on average differences in achievement across MSAs.

Our education exposure measure is greater than 0 if blacks differentially live in census tracts with more educated people, and less than 0 if they differentially live in census tracts with less educated people. The first row of Table 9 shows the summary statistics for the educational exposure measure. The mean is -.086 and the standard deviation is .044 .

We have also formed a measure of the income exposure of blacks, similar to that for education exposure. The two measures are highly correlated (about $0.7)$, so we report results only for the measure of education exposure.

The next hypothesis is that segregation operates through parental influences alone. In this scenario the parental generation was marred in some way by segregation, and this damage has been passed to the children. This model suggests that neighborhood and segregation are only really important as a proxy for (and perhaps a determinant of) family characteristics. We use two variables for family background: the proportion of women in the 40-60 year old age group who are unmarried but have children; and the proportion of men in the same age group with some amount of college education. In both cases we have normalized these variables by subtracting the means of these variables for whites in the MSA. As the next rows of Table 9 show, 24.7\% more black women are single mothers than white women, and $17.3 \%$ fewer black men have had some college education.

The final variable is the average time to work for employed blacks relative to employed whites. This variable is meant to capture how far the jobs are from black residences. Of course, this variable only includes the jobs where blacks are in fact employed. This number may therefore undercount the true 
distance between blacks and the relevant jobs. As the last row of Table 9 shows, blacks and whites live virtually the same distance from jobs.

The second panel in Table 9 shows the correlation of the four variables with each other and with our measure of housing segregation. The strongest correlations are between housing segregation, education exposure measure and single motherhood in the parental generation. The single motherhood result confirms the connection between segregation and single motherhood that we found for the younger generation.

The other variables are more weakly correlated. Black male parental education is positively correlated with educational exposure. In part this is unsurprising since educational exposure will rise as the number of educated blacks rises. Time to work is only weakly correlated with the other potential explanatory variables.

Table 10 puts these different explanatory variables in our basic OLS regressions from Table 4 and examines what their inclusion does to the coefficient on segregation for 25-30 year old individuals. We are using OLS estimates here for simplicity since we do not have adequate instruments for all the different hypotheses. Our belief is that since the instrumenting did not significantly change the coefficients on segregation, this OLS approach is appropriate for checking the robustness of our results to including these other explanatory variables. This table includes the same MSA-level and demographic controls as Table 4.

Table 10 shows that the education, parental and travel variables are related to poor outcomes. The share of blacks that get a high school or college education rises with exposure to educated people, and the probability of a black female being a single mother declines with exposure to the educated. In cities where the parental generation had more single mothers, the children are more likely to become single mothers; and having a more educated father increases the probability that a black child will receive a college degree. Finally, a greater time distance from work for blacks is associated with an increased probability of being idle and lower wages conditional on working. 
Still, including these additional variables does not eliminate the effects of segregation on outcomes. For high school graduation, idleness, earnings, and the probability of being a single mother, the segregation coefficient is statistically and economically significant. Indeed, as the last row of Table 10 shows these alternative factors in total explain about 20 to 40 percent of the effects of segregation. Thus, some of the effects of segregation appear to be due to spillovers or commuting costs, but there is still a substantial residual to be explained.

\section{Conclusion}

This paper has documented that blacks are significantly worse off in segregated communities than they are in non-segregated communities. If we measure success with high-school graduation rates, or not being idle, or earnings, or not becoming a single mother, then integration is intimately associated with success. Our attempts to deal with causality suggests that the causal direction runs from ghettos to failure, not from failure to ghettos. We also tried to determine the mechanism by which ghettos hurt blacks. We found some evidence supporting lack of education exposure, poor parental attributes and distance from jobs. However, none of these variables explains a large portion of the effect of segregation.

Despite our overall finding that segregation is costly for African-Americans, we do not take these findings to mean that ghettos always and everywhere have been forces for ill. The anecdotal evidence supporting a positive role for ghettos among early 20th century immigrant communities makes us suspect that ghettos can play both positive and negative roles. Chiswick (1991) finds that in 1900, Jews living in cities did substantially better than Jews outside of cities and that this affect is stronger than the urban premium for Gentiles. While urban residence is no guarantee of being a ghetto dweller, cities and ghettos are correlated, so Chiswick's work is tenuously suggestive of a ghetto premium for Jews in 1900. But future research will be needed before we can confirm that ghettos do anything but harm minorities.

We also hope that future research can better isolate why ghettos seem to be so bad for African-Americans. Our research has provided no evidence on 
whether outcomes are related to underprovision of local public goods, and it is a possibility that one of the costs of segregation to the poor is that they receive less in government expenditures. Future work should seek to improve our understanding of the mechanisms by which ghettos create economic problems. 


\section{References}

Benabou, R. (1993) "Workings of a City: Location, Education and Production," mimeographed.

Borjas, G. (1992) "Ethnicity, Neighborhoods, and Human Capital Externalities," NBER Working Paper \# 4912.

Case, A. and L. Katz (1991) "The Company You Keep: The Effect of Family and Neighborhood on Disadvantaged Youth," NBER Working Paper \# 3705.

Chiswick, B. (1991) "Jewish Immigrant Skill and Occupational Attainment at the Turn of the Century," Exploration in Economic History 28: 64-86.

Coleman, J. et al. (1966) Equality of Educational Opportunity. Washington: U.S. Office of Education.

Crane, J. (1991) "The Epidemic Theory of Ghettos and Neighborhood Effects on Dropping Out and Teenage Childbearing," American Journal of Sociology 96.

Cutler, D., D. Elmendorf and R. Zeckhauser (1993) "Demographic Characteristics and the Public Bundle," Public Finance 48: 178-198.

DiPasquale, D. and E. Glaeser (1994) "The L.A. Riot and the Economics of Urban Unrest," mimeographed.

Douglas, A. (1995) Terrible Honesty: Mongrel Manhattan in the 1920s. New York: Farrar, Straus and Giroux.

Ellwood, D. (1986) "The Spatial Mismatch Hypothesis: Are There Teen-Age Jobs Missing in the Ghetto?" in R. Freeman and H. Holzer eds. The Black Youth Employment Crisis. Chicago: University of Chicago Press.

Glaeser, E., B. Sacerdote and J.Scheinkman (1995) "Crime and Social Interactions," NBER Working Paper \# 5026.

Glaeser, E. and D. Maré (1994) "Cities and Skills," Hoover Institution Working Paper E-94-11.

Glazer, N. and D. Moynihan (1963) Beyond the Melting Pot. Cambridge: MIT Press.

Handlin, O. (1959) The Uprooted Cambridge: Harvard University Press.

Holzer, H. (1991) "The Spatial Mismatch Hypothesis: What Has the Evidence Shown?" Urban Studies 28: 105-122.

Hoxby, C. M. (1995) "Does Competition Among Public Schools Benefit Students and Taxpayers," NBER Working Paper \# 4979.

Ihlanfeldt, K. and D. Sjoquist (1990) "Job Accessibility and Racial Differences in Youth Unemployment Rates," American Economic Review 80: 267-276.

Jenks, C. and S, Meyer (1990) "Residential Segregation, Job Proximity, and Black Job Opportunities," in L. Lynn and M. McGreary eds. Inner-City Poverty in the United States. Washington: National Academic Press.

Kain, J. (1992) "The Spatial Mismatch Hypothesis: Three Decades Together," Housing Policy Debate 3: 371-462.

Kain, J. (1968) "Housing Segregation, Negro Employment, and Metropolitan Decentralization," Quarterly Journal of Economics 82: 175-197.

Kasarda, J (1989) "Urban Industrial Transition and the Underclass," Annals of the American Academy of Political and Social Science 501: 26-47. 


\section{References Continued}

Lazear, E. (1995) "Culture and Language," mimeographed.

Massey, D. and N. A. Denton (1993) American Apartheid: Segregation and the Making of the Underclass. Cambridge: Harvard University Press.

Quigley, J. and K. O'Regan (1994) "Teenage Employment and the Spatial Isolation of Minority and Poverty Households," mimeographed.

Schelling, T. (1978) Micromotives and Macrobehavior. New York: Norton.

Taeuber, K. and A. Taeuber (1965) Negroes in Cities. Chicago: Aldine.

Tiebout, C. (1958) "A Pure Theory of Local Expenditures," Journal of Political Economy 64: 416-424.

Wilson, W. (1987) The Truly Disadvantaged: The Inner City, the Underclass, and Public Policy. Chicago: University of Chicago Press.

Wirth, L. (1956) The Ghetto. Chicago: University of Chicago Press. 


\section{CHART 1: EQUILIBRIA AS A FUNCTION OF DISCRIMINATION (D)}

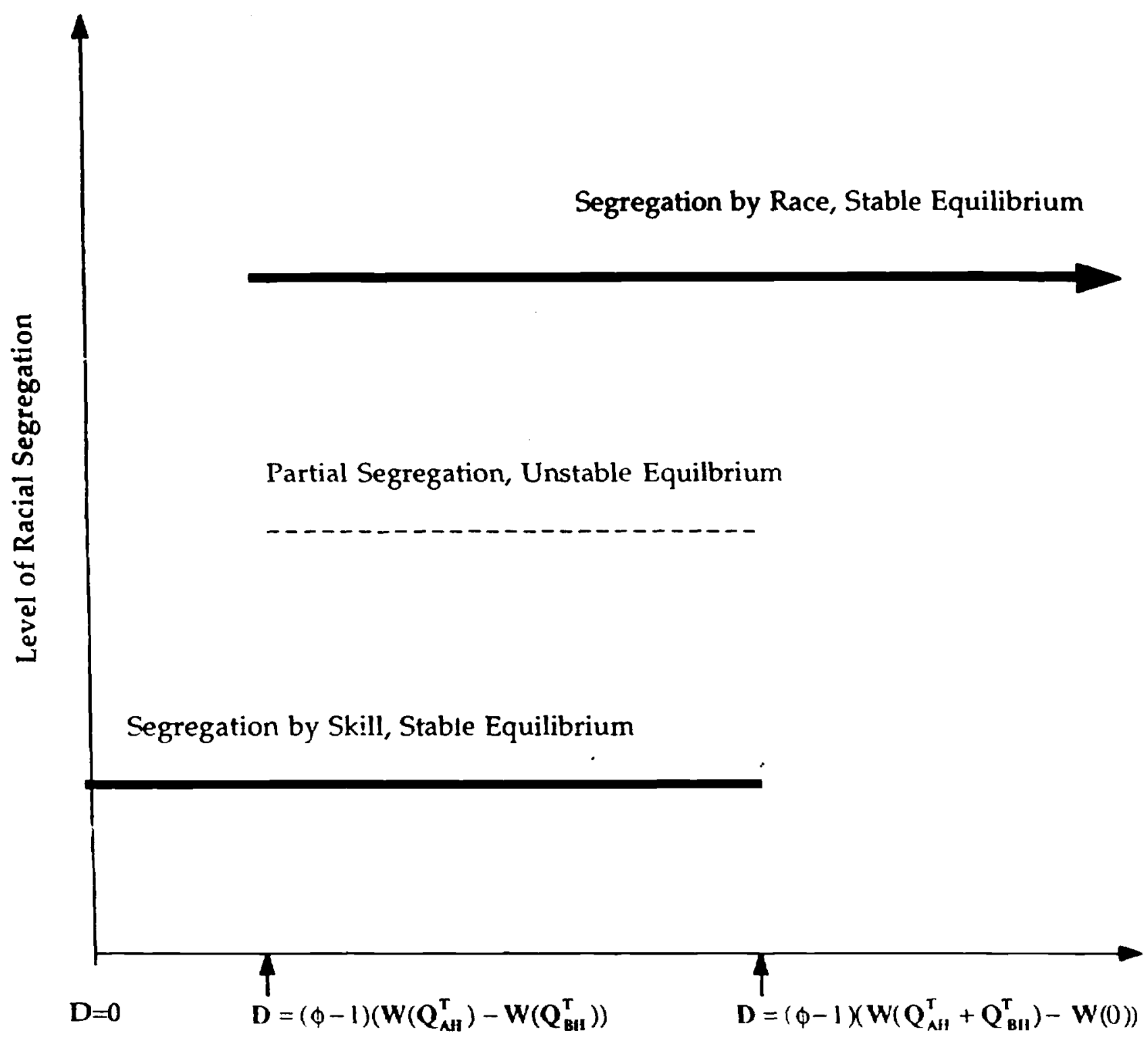

Quantity of Discrimation (D)

Discrimination is defined as the cost to minorities of moving out of the ghetto area

For low levels of discrimination only the segregation by skill equilibrium exists (and the unstable total integration equilibrium at $\mathrm{D}=0$ ). For middle levels of discrimination all three equilibria exist and for high levels of discrimination only the equilibrium with segregation by race exists. 
CHART 2: SEGREGATION IN THEORY

\begin{tabular}{|c|c|}
\hline Race A, Wealth $\mathbf{H}$ & Race B, Wealth H \\
\hline $\begin{array}{c}\text { Segregation by Race, } \\
D \geq(\phi-1)\left(W\left(Q_{A H}^{T}\right)-W\left(Q_{B H}^{T}\right)\right) \\
\text { Utility }=\phi W\left(Q_{A H}^{T}\right)-C \\
C=W\left(Q_{A H}^{T}\right)-W\left(Q_{B H}^{T}\right)\end{array}$ & $\begin{array}{c}\text { Segregation by Race, } \\
D \geq(\phi-1)\left(W\left(Q_{A H}^{T}\right)-W\left(Q_{B H}^{T}\right)\right) \\
\text { Utility }=\phi W\left(Q_{B H}^{T}\right)\end{array}$ \\
\hline $\begin{array}{c}\text { Segregation by Skill, } \\
\begin{array}{c}D \leq(\phi-1)\left(W\left(Q_{A H}^{T}+Q_{B H}^{T}\right)-W(0)\right) \\
\text { Utility }=\phi W\left(Q_{A H}^{T}+Q_{B H}^{T}\right)-C \\
C=W\left(Q_{A H}^{T}+Q_{B H}^{T}\right)-W(0)\end{array}\end{array}$ & $\begin{array}{c}\text { Segregation by Skill, } \\
D \leq(\phi-1)\left(W\left(Q_{A H}^{T}+Q_{B H}^{T}\right)-W(0)\right) \\
\text { Utility }=\phi W\left(Q_{A H}^{T}+Q_{B H}^{T}\right)-C-D \\
C=W\left(Q_{A H}^{T}+Q_{B H}^{T}\right)-W(0)\end{array}$ \\
\hline $\begin{array}{c}\text { Total Integration } \\
\text { Utility }=\phi W\left(\frac{Q_{A H}^{T}+Q_{B H}^{T}}{2}\right)\end{array}$ & $\begin{array}{c}\text { Total Integration } \\
\text { Utility }=\phi W\left(\frac{Q_{A H}^{T}+Q_{B H}^{T}}{2}\right)\end{array}$ \\
\hline Race A, Wealth L & Race B, Wealth L \\
\hline $\begin{array}{c}\text { Segregation by Race, } \\
D \geq(\phi-1)\left(W\left(Q_{A H}^{T}\right)-W\left(Q_{B H}^{T}\right)\right) \\
\text { Utility }=W\left(Q_{B H}^{T}\right)=W\left(Q_{A H}^{T}\right)-C\end{array}$ & $\begin{array}{c}\text { Segregation by Race, } \\
D \geq(\phi-1)\left(W\left(Q_{A H}^{T}\right)-W\left(Q_{H I I}^{T}\right)\right) \\
\text { Utility }=W\left(Q_{B H}^{T}\right)\end{array}$ \\
\hline $\begin{array}{c}\text { Segregation by Skill, } \\
D \leq(\phi-1)\left(W\left(Q_{A H}^{T}+Q_{B H}^{T}\right)-W(0)\right) \mathrm{o} \\
\text { Utility }=W(0)=W\left(Q_{A H}^{T}+Q_{B H}^{T}\right)-C\end{array}$ & $\begin{array}{c}\text { Segregation by Skill, } \\
D \leq(\phi-1)\left(W\left(Q_{A H}^{T}+Q_{B H}^{T}\right)-W(0)\right) \\
\text { Utility }=W(0)\end{array}$ \\
\hline $\begin{array}{l}\text { Total Integration, } \mathrm{D}=0 \\
\text { Utility }=W\left(\frac{Q_{A l t}^{r}+Q_{R H}^{r}}{2}\right)\end{array}$ & $\begin{array}{l}\text { Total Integration, } \mathrm{D}=0 \\
\text { Utility }=W\left(\frac{Q_{A l}^{T}+Q_{H I}^{T}}{2}\right)\end{array}$ \\
\hline
\end{tabular}




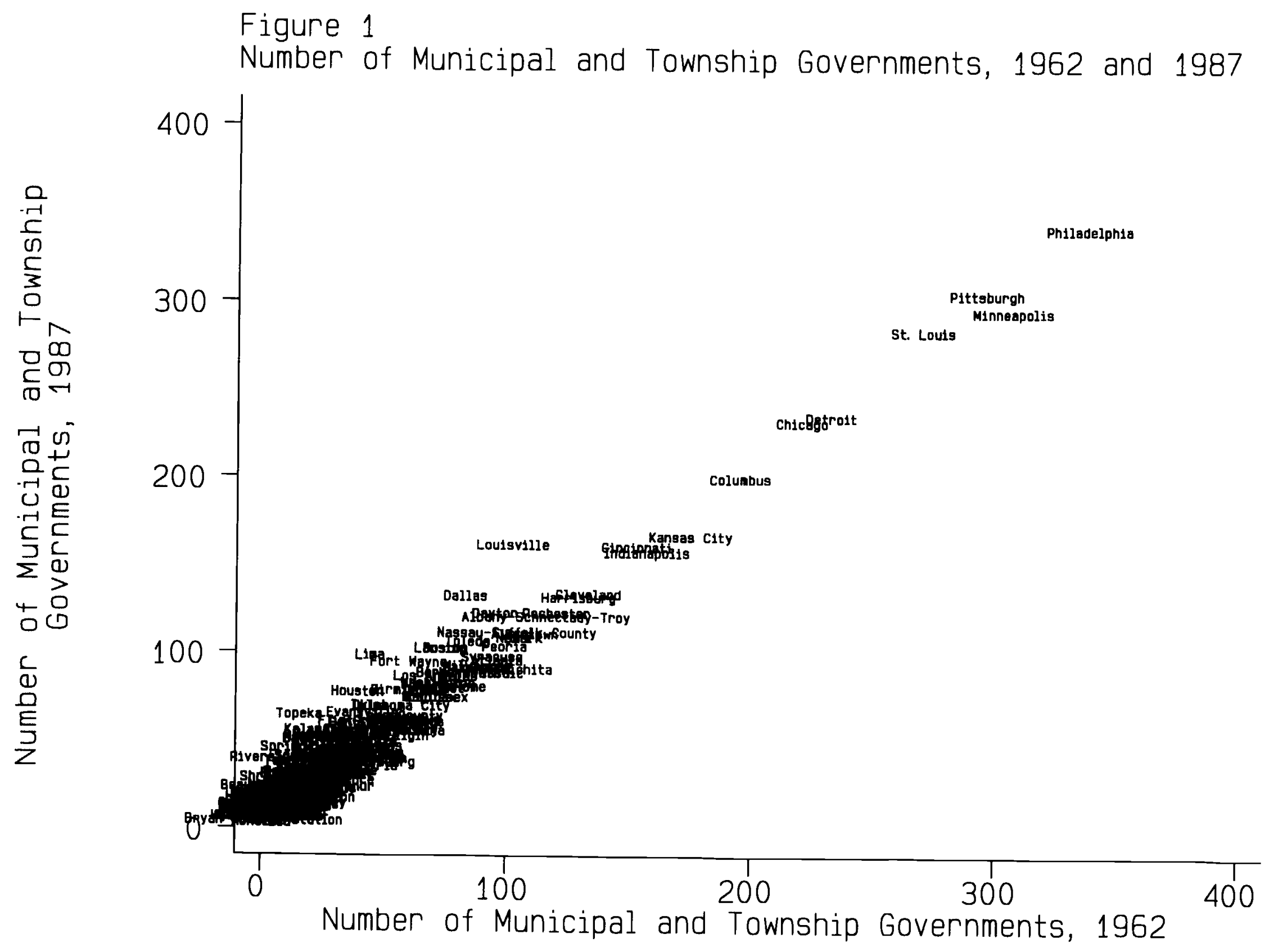


Figure 2

Segregation and the Number of Municipal and Township Governments

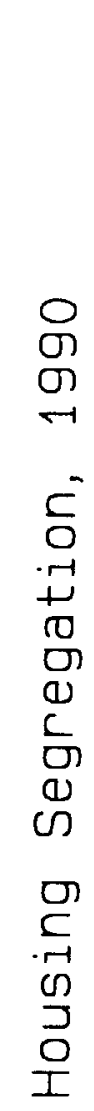

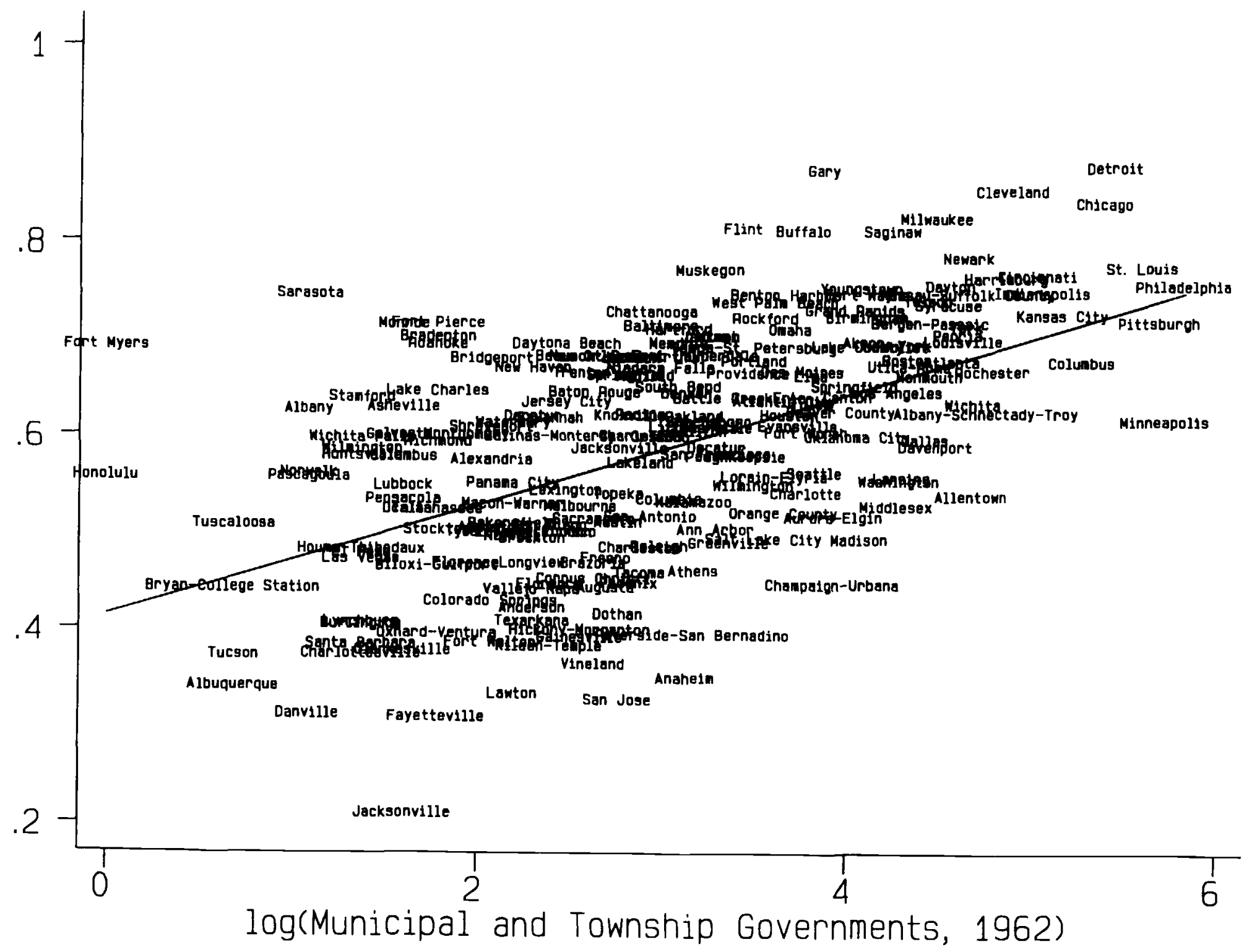


Figure 3

Share of Local Revenue from Other Gorvernments, 1962 and 1988

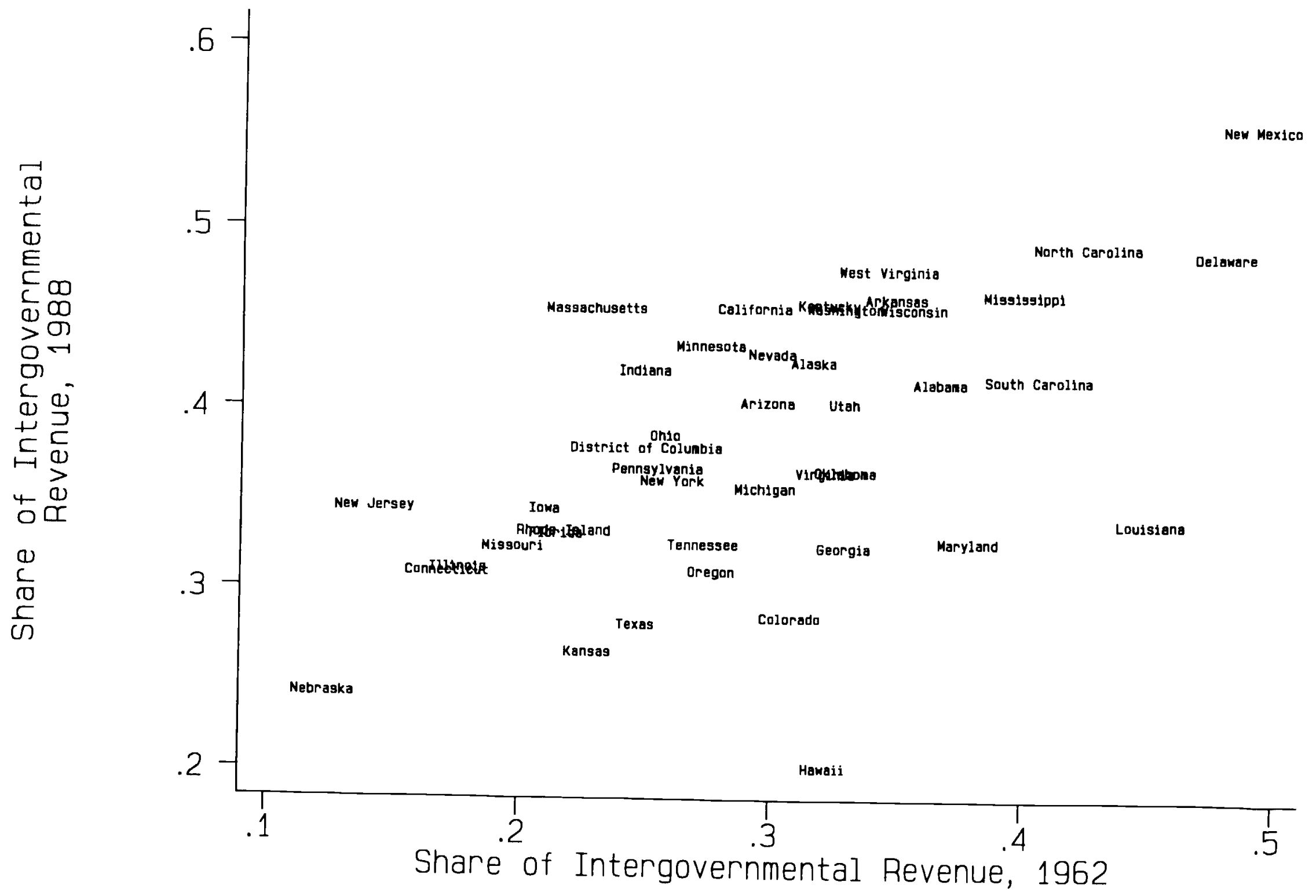


Figure 4

Segregation and the Share of Intergovernmental Revenue

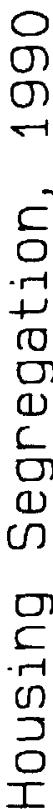

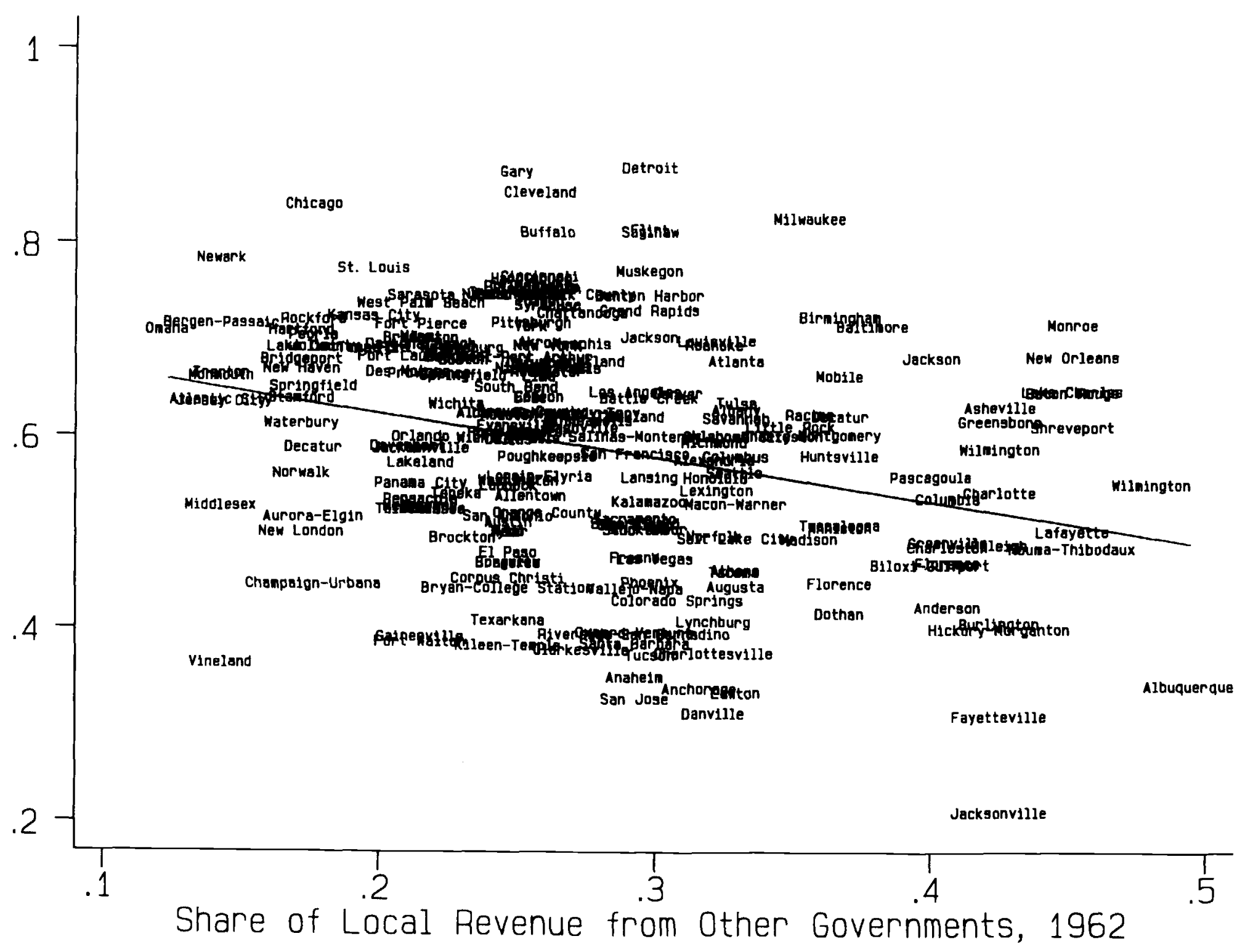


Table 1: Measuring Segregation

\begin{tabular}{|c|c|c|c|c|c|}
\hline Measure & $\begin{array}{l}\text { Number of } \\
\text { Observations }\end{array}$ & Mean & $\begin{array}{l}\text { Standard } \\
\text { Deviation }\end{array}$ & Minimum & Maximum \\
\hline Housing Segregation & 209 & .586 & .126 & .206 & .873 \\
\hline Number of Governments & 208 & 40 & 55 & 1 & 339 \\
\hline \multirow{3}{*}{$\begin{array}{l}\text { Percent of Revenue from } \\
\text { Intergovernmental Transfers }\end{array}$} & 209 & .283 & .078 & .123 & 494 \\
\hline & \multicolumn{3}{|c|}{ Correlations } & & \\
\hline & $\begin{array}{l}\text { Housing } \\
\text { Segregation }\end{array}$ & $\begin{array}{l}\text { Number of } \\
\text { Govs. }\end{array}$ & $\begin{array}{l}\text { Percent of } \\
\text { Intergov. } \\
\text { Revenue }\end{array}$ & & \\
\hline Housing Segregation & 1.000 & & & & \\
\hline Number of Governments & .481 & 1.000 & & & \\
\hline $\begin{array}{l}\text { Percent of Revenue from } \\
\text { Intergovernmental Transfers }\end{array}$ & -.295 & -.232 & 1.000 & & \\
\hline
\end{tabular}


Table 2: Summary Statistics

\begin{tabular}{|c|c|c|}
\hline Variable & Age 20-24 & Age $25-30$ \\
\hline \multicolumn{3}{|l|}{ Education } \\
\hline High School Graduate & $85.3 \%$ & $87.4 \%$ \\
\hline College Graduate & $12.1 \%$ & $25.1 \%$ \\
\hline \multicolumn{3}{|l|}{ Work and Income } \\
\hline Idle & $8.8 \%$ & $10.9 \%$ \\
\hline ln(Earnings) & 9.0 & 9.5 \\
\hline \multicolumn{3}{|l|}{ Social } \\
\hline Unmarried Mother & $14.5 \%$ & $16.5 \%$ \\
\hline \multicolumn{3}{|l|}{ Demographic Variables } \\
\hline Black & $15.0 \%$ & $13.4 \%$ \\
\hline Asian & $1.2 \%$ & $1.0 \%$ \\
\hline Other Non-White & $0.7 \%$ & $0.6 \%$ \\
\hline Hispanic & $7.6 \%$ & $6.0 \%$ \\
\hline Female & $50.1 \%$ & $51.2 \%$ \\
\hline $\mathrm{N}$ & 97,976 & 139,715 \\
\hline \multicolumn{3}{|c|}{$\begin{array}{l}\text { Note: The data are from the } 1 \text { percent sample of the } 1990 \\
\text { Census. Observations are for native-born people living in one } \\
\text { of } 204 \text { MSAs where segregation and public finance variables } \\
\text { are available and can be matched to the micro data. Earnings } \\
\text { data are restricted to } 56,627 \text { and } 105,997 \text { people who are } \\
\text { working, not enrolled in school, and have non-negative } \\
\text { earnings. Unmarried mother data are restricted to } 49,038 \text { and } \\
71,531 \text { women. }\end{array}$} \\
\hline
\end{tabular}


Table 3: Preliminary Evidence on the Relation Between Segregation and Outcomes

\begin{tabular}{|c|c|c|c|c|c|c|c|c|c|c|}
\hline & \multicolumn{5}{|c|}{ Age 20-24 } & \multicolumn{5}{|c|}{ Age $25-30$} \\
\hline & \multicolumn{2}{|c|}{ Education } & \multicolumn{2}{|c|}{ Income } & \multirow{2}{*}{$\begin{array}{c}\text { Social } \\
\text { Single } \\
\text { Mother }\end{array}$} & \multicolumn{2}{|c|}{ Education } & \multicolumn{2}{|c|}{ Income } & \multirow{2}{*}{$\begin{array}{l}\text { Social } \\
\text { Single } \\
\text { Mother }\end{array}$} \\
\hline & $\begin{array}{c}\text { HS } \\
\text { Graduate }\end{array}$ & $\begin{array}{c}\text { College } \\
\text { Graduate }\end{array}$ & Idle & $\ln ($ Earn $)$ & & $\begin{array}{c}\text { HS } \\
\text { Graduate }\end{array}$ & $\begin{array}{l}\text { College } \\
\text { Graduate }\end{array}$ & Idle & $\ln ($ Earn $)$ & \\
\hline \multicolumn{11}{|l|}{ Black } \\
\hline Low Segregation & $79.5 \%$ & $4.8 \%$ & $15.0 \%$ & 8.79 & $35.8 \%$ & $80.1 \%$ & $11.7 \%$ & $15.4 \%$ & 9.22 & $39.8 \%$ \\
\hline High Segregation & 73.6 & 4.7 & 22.2 & 8.59 & 40.5 & 76.9 & 11.6 & 21.8 & 9.11 & 46.0 \\
\hline Difference & -5.9 & -0.1 & 7.2 & -0.20 & 4.7 & -3.2 & -0.1 & 6.4 & -0.11 & 6.2 \\
\hline \multicolumn{11}{|l|}{ Non-Black } \\
\hline Low Segregation & $87.1 \%$ & $11.4 \%$ & $6.8 \%$ & 9.04 & $10.5 \%$ & $88.5 \%$ & $25.6 \%$ & $9.6 \%$ & 9.54 & $12.7 \%$ \\
\hline High Segregation & 87.2 & 14.4 & 6.8 & 9.05 & 9.5 & 89.1 & 28.0 & 9.5 & 9.56 & 11.4 \\
\hline Difference & 0.1 & 3.0 & 0.0 & 0.01 & -1.0 & 0.6 & 2.4 & -0.1 & 0.02 & -1.3 \\
\hline $\begin{array}{l}\text { Difference-in- } \\
\text { Difference (B-W) }\end{array}$ & $\begin{array}{l}-6.0 \% \\
(0.7 \%)\end{array}$ & $\begin{array}{l}-3.1 \% \\
(0.6 \%)\end{array}$ & $\begin{array}{l}7.2 \% \\
(0.5 \%)\end{array}$ & $\begin{array}{l}-0.22 \\
(0.03)\end{array}$ & $\begin{array}{c}5.8 \% \\
(0.9 \%)\end{array}$ & $\begin{array}{l}-3.7 \% \\
(0.6 \%)\end{array}$ & $\begin{array}{l}-2.5 \% \\
(0.7 \%)\end{array}$ & $\begin{array}{c}6.5 \% \\
(0.5 \%)\end{array}$ & $\begin{array}{l}-0.13 \\
(0.02)\end{array}$ & $\begin{array}{c}7.5 \% \\
(0.8 \%)\end{array}$ \\
\hline
\end{tabular}

Note: High segregation MSAs are MSAs with housing segregation above the mean. 
Table 4: OLS Estimates of the Effects of Segregation on Outcomes

\begin{tabular}{|c|c|c|c|c|c|c|c|c|c|c|}
\hline \multirow[b]{2}{*}{$\begin{array}{l}\text { Independent } \\
\text { Variable }\end{array}$} & \multicolumn{5}{|c|}{ Age $20-24$} & \multicolumn{5}{|c|}{ Age $25-30$} \\
\hline & $\begin{array}{c}\text { HS } \\
\text { Graduate }\end{array}$ & $\begin{array}{c}\text { College } \\
\text { Graduate }\end{array}$ & Idle & $\ln ($ Earn $)$ & $\begin{array}{c}\text { Social } \\
\text { Single } \\
\text { Mother }\end{array}$ & $\begin{array}{c}\text { HS } \\
\text { Graduate }\end{array}$ & $\begin{array}{c}\text { College } \\
\text { Graduate }\end{array}$ & Idle & $\ln ($ Earn $)$ & $\begin{array}{l}\text { Social } \\
\begin{array}{l}\text { Single } \\
\text { Mother }\end{array}\end{array}$ \\
\hline \multicolumn{11}{|l|}{ Segregation } \\
\hline Segregation & $\begin{array}{c}-005 \\
(.032)\end{array}$ & $\begin{array}{c}.039 \\
(.045)\end{array}$ & $\begin{array}{c}.002 \\
(.018)\end{array}$ & $\begin{array}{c}-.026 \\
(.066)\end{array}$ & $\begin{array}{c}.022 \\
(.029)\end{array}$ & $\begin{array}{c}.000 \\
(.025)\end{array}$ & $\begin{array}{l}-.071 \\
(.079)\end{array}$ & $\begin{array}{l}.008 \\
(.024)\end{array}$ & $\begin{array}{c}-.084 \\
(.065)\end{array}$ & $\begin{array}{c}-.010 \\
(.025)\end{array}$ \\
\hline \multicolumn{11}{|l|}{ Demographics } \\
\hline Black & $\begin{array}{c}-.513 \\
(.322)\end{array}$ & $\begin{array}{c}.028 \\
(.346)\end{array}$ & $\begin{array}{c}.292 \\
(.295)\end{array}$ & $\begin{array}{r}-1.516 \\
(.754)\end{array}$ & $\begin{array}{c}.545 \\
(.319)\end{array}$ & $\begin{array}{l}-.205 \\
(.325)\end{array}$ & $\begin{array}{c}.227 \\
(.580)\end{array}$ & $\begin{array}{c}.426 \\
(.230)\end{array}$ & $\begin{array}{l}-.801 \\
(.532)\end{array}$ & $\begin{array}{c}.616 \\
(.337)\end{array}$ \\
\hline Hispanic & $\begin{array}{c}-.160 \\
(.013)\end{array}$ & $\begin{array}{c}-.090 \\
(.012)\end{array}$ & $\begin{array}{l}.086 \\
(.010)\end{array}$ & $\begin{array}{l}-.153 \\
(.023)\end{array}$ & $\begin{array}{c}.128 \\
(.015)\end{array}$ & $\begin{array}{c}-.159 \\
(.012)\end{array}$ & $\begin{array}{c}-.181 \\
(.019)\end{array}$ & $\begin{array}{c}.062 \\
(.009)\end{array}$ & $\begin{array}{c}-.216 \\
(.022)\end{array}$ & $\begin{array}{c}.146 \\
(.015)\end{array}$ \\
\hline Female & $\begin{array}{l}.029 \\
(.002)\end{array}$ & $\begin{array}{l}.026 \\
(.003)\end{array}$ & $\begin{array}{l}.054 \\
(.003)\end{array}$ & $\begin{array}{l}-.278 \\
(015)\end{array}$ & --- & $\begin{array}{c}.024 \\
(.002)\end{array}$ & $\begin{array}{c}.004 \\
(.003)\end{array}$ & $\begin{array}{l}.106 \\
(.003)\end{array}$ & $\begin{array}{l}-.449 \\
(.016)\end{array}$ & --- \\
\hline
\end{tabular}


Table 4 (continued)

\begin{tabular}{|c|c|c|c|c|c|c|c|c|c|c|}
\hline \multirow[b]{3}{*}{$\begin{array}{l}\text { Independent } \\
\text { Variable }\end{array}$} & \multicolumn{5}{|c|}{ Age $20-24$} & \multicolumn{5}{|c|}{ Age $25-30$} \\
\hline & \multicolumn{2}{|c|}{ Education } & \multicolumn{2}{|c|}{ Income } & \multirow{2}{*}{$\begin{array}{l}\text { Social } \\
\begin{array}{l}\text { Single } \\
\text { Mother }\end{array}\end{array}$} & \multicolumn{2}{|c|}{ Education } & \multicolumn{2}{|c|}{ İncome } & \multirow{2}{*}{$\begin{array}{l}\text { Social } \\
\text { Single } \\
\text { Mother }\end{array}$} \\
\hline & $\begin{array}{c}\text { HS } \\
\text { Graduate }\end{array}$ & $\begin{array}{l}\text { College } \\
\text { Graduate }\end{array}$ & Idle & $\ln ($ Earn $)$ & & $\begin{array}{c}\text { HS } \\
\text { Graduate }\end{array}$ & $\begin{array}{l}\text { College } \\
\text { Graduate }\end{array}$ & Idle & $\ln ($ Earn $)$ & \\
\hline$\frac{\text { MSA Characs. }}{\ln (\text { Population })}$ & $\begin{array}{l}.006 \\
(.004)\end{array}$ & $\begin{array}{l}.017 \\
(.005)\end{array}$ & $\begin{array}{r}-.003 \\
(.002)\end{array}$ & $\begin{array}{l}-.003 \\
(.008)\end{array}$ & $\begin{array}{l}-.005 \\
(.003)\end{array}$ & $\begin{array}{l}.015 \\
(.003)\end{array}$ & $\begin{array}{c}.049 \\
(.008)\end{array}$ & $\begin{array}{l}-.008 \\
(.002)\end{array}$ & $\begin{array}{c}.031 \\
(.008)\end{array}$ & $\begin{array}{l}-.009 \\
(.003)\end{array}$ \\
\hline $\begin{array}{l}\ln (\text { Population }) * \\
\text { Black }\end{array}$ & $\begin{array}{l}.005 \\
(.005)\end{array}$ & $\begin{array}{l}-.012 \\
(.005)\end{array}$ & $\begin{array}{l}-.005 \\
(.005)\end{array}$ & $\begin{array}{l}.047 \\
(.016)\end{array}$ & $\begin{array}{l}-.030 \\
(.006)\end{array}$ & $\begin{array}{l}.000 \\
(.005)\end{array}$ & $\begin{array}{l}-.030 \\
(.007)\end{array}$ & $\begin{array}{l}.002 \\
(.004)\end{array}$ & $\begin{array}{l}.022 \\
(.010)\end{array}$ & $\begin{array}{l}-.027 \\
(.006)\end{array}$ \\
\hline Percent black & $\begin{array}{l}-.053 \\
(.043)\end{array}$ & $\begin{array}{l}.085 \\
(.062)\end{array}$ & $\begin{array}{l}.006 \\
(.021)\end{array}$ & $\begin{array}{l}.435 \\
(.098)\end{array}$ & $\begin{array}{l}-.110 \\
(.028)\end{array}$ & $\begin{array}{l}-.088 \\
(.033)\end{array}$ & $\begin{array}{l}.183 \\
(.093)\end{array}$ & $\begin{array}{l}-.003 \\
(.023)\end{array}$ & $\begin{array}{c}.498 \\
(.075)\end{array}$ & $\begin{array}{l}-.102 \\
(.031)\end{array}$ \\
\hline $\begin{array}{l}\text { Percent black * } \\
\text { Black }\end{array}$ & $\begin{array}{l}-.007 \\
(.075)\end{array}$ & $\begin{array}{l}-.116 \\
(.051)\end{array}$ & $\begin{array}{l}.008 \\
(.055)\end{array}$ & $\begin{array}{l}-.364 \\
(.167)\end{array}$ & $\begin{array}{l}.017 \\
(.061)\end{array}$ & $\begin{array}{l}-.091 \\
(.065)\end{array}$ & $\begin{array}{l}-.153 \\
(.081)\end{array}$ & $\begin{array}{l}-.103 \\
(.048)\end{array}$ & $\begin{array}{l}-.409 \\
(.147)\end{array}$ & $\begin{array}{l}-.057 \\
(.071)\end{array}$ \\
\hline $\ln ($ Med. Income) & $\begin{array}{c}.024 \\
(.021)\end{array}$ & $\begin{array}{l}-.004 \\
(.043)\end{array}$ & $\begin{array}{l}-.058 \\
(.009)\end{array}$ & $\begin{array}{l}.609 \\
(.050)\end{array}$ & $\begin{array}{l}-.008 \\
(.013)\end{array}$ & $\begin{array}{c}.031 \\
(.024)\end{array}$ & $\begin{array}{l}.047 \\
(.075)\end{array}$ & $\begin{array}{l}-.077 \\
(.014)\end{array}$ & $\begin{array}{l}.594 \\
(.031)\end{array}$ & $\begin{array}{l}-.045 \\
(.024)\end{array}$ \\
\hline $\begin{array}{l}\text { In(Med. Income)* } \\
\text { Black }\end{array}$ & $\begin{array}{l}.049 \\
(.028)\end{array}$ & $\begin{array}{l}.009 \\
(.034)\end{array}$ & $\begin{array}{l}-.028 \\
(.027)\end{array}$ & $\begin{array}{l}.101 \\
(.062)\end{array}$ & $\begin{array}{l}. .002 \\
(.028)\end{array}$ & $\begin{array}{c}.024 \\
(.029)\end{array}$ & $\begin{array}{l}.005 \\
(.055)\end{array}$ & $\begin{array}{l}-.050 \\
(.019)\end{array}$ & $\begin{array}{l}.047 \\
(.045)\end{array}$ & $\begin{array}{l}-.018 \\
(.029)\end{array}$ \\
\hline Summary & & & & & & & & & & \\
\hline $\mathrm{N}$ & 97,976 & 97,976 & 97,976 & 56,627 & 49,038 & 139,715 & 139,715 & 139,715 & 105,997 & 71,531 \\
\hline $\mathrm{R}^{2}$ & .034 & .093 & .050 & .090 & .108 & .031 & .039 & .050 & .096 & .109 \\
\hline
\end{tabular}


Table 5: IV Estimates of the Effect of Segregation on Outcomes

\begin{tabular}{|c|c|c|c|c|c|c|c|c|c|c|}
\hline \multirow[b]{2}{*}{$\begin{array}{l}\text { Independent } \\
\text { Variable }\end{array}$} & \multicolumn{5}{|c|}{ Age $20-24$} & \multicolumn{5}{|c|}{ Age 25-30 } \\
\hline & $\begin{array}{c}\text { HS } \\
\text { Graduate }\end{array}$ & $\begin{array}{l}\text { College } \\
\text { Graduate }\end{array}$ & Idle & $\ln ($ Earn $)$ & $\begin{array}{c}\text { Social } \\
\text { Single } \\
\text { Mother }\end{array}$ & $\begin{array}{c}\text { HS } \\
\text { Graduate }\end{array}$ & $\begin{array}{l}\text { College } \\
\text { Graduate }\end{array}$ & Idle & $\ln ($ Earn $)$ & $\begin{array}{l}\text { Social } \\
\text { Single } \\
\text { Mother }\end{array}$ \\
\hline \multicolumn{11}{|c|}{ A. Instruments for Within-MSA Mobility } \\
\hline $\begin{array}{l}\text { Segregation * } \\
\text { Black }\end{array}$ & $\begin{array}{l}-.357 \\
(.043)\end{array}$ & $\begin{array}{l}-.154 \\
(.039)\end{array}$ & $\begin{array}{l}.321 \\
(.040)\end{array}$ & $\begin{array}{r}-1.059 \\
(.144)\end{array}$ & $\begin{array}{l}.306 \\
(.056)\end{array}$ & $\begin{array}{l}-.193 \\
(.045)\end{array}$ & $\begin{array}{l}-.058 \\
(.057)\end{array}$ & $\begin{array}{l}.310 \\
(.036)\end{array}$ & $\begin{array}{l}-.559 \\
(.108)\end{array}$ & $\begin{array}{l}.574 \\
(.059)\end{array}$ \\
\hline $\mathrm{N}$ & 97,976 & 97,976 & 97,976 & 56,627 & 49,038 & 139,715 & 139,715 & 139,715 & 105,997 & 71,531 \\
\hline $\mathrm{R}^{2}$ & .033 & .091 & .049 & .090 & .108 & .031 & .038 & .050 & .096 & .108 \\
\hline \multicolumn{11}{|c|}{ B. Instruments for Cross-MSA Mobility } \\
\hline $\begin{array}{l}\text { Segregation* } \\
\text { Black }\end{array}$ & $\begin{array}{l}-.346 \\
(.045)\end{array}$ & $\begin{array}{l}-.171 \\
(.040)\end{array}$ & $\begin{array}{c}.301 \\
(.043)\end{array}$ & $\begin{array}{l}-1.207 \\
(.155)\end{array}$ & $\begin{array}{l}.142 \\
(.066)\end{array}$ & $\begin{array}{l}-.256 \\
(.047)\end{array}$ & $\begin{array}{l}-.172 \\
(.061)\end{array}$ & $\begin{array}{c}.387 \\
(.039)\end{array}$ & $\begin{array}{l}-.669 \\
(.117)\end{array}$ & $\begin{array}{c}.650 \\
(.067)\end{array}$ \\
\hline $\mathrm{N}$ & 87,062 & 87,062 & 87,062 & 50,002 & 43,602 & 125,636 & 125,636 & 125,636 & 95,211 & 64,773 \\
\hline $\mathrm{R}^{2}$ & .031 & .085 & .050 & .088 & .112 & .031 & .038 & .049 & .096 & .112 \\
\hline
\end{tabular}

Note: Regressions include the same set of controls as in Table 4. The instruments for within-MSA mobility are the logarithm of the number of governments in 1962 and its interaction with black, the percent of revenue from intergovernmental transfers in 1962 and its interaction with black. The instruments for cross-MSA mobility are these variables for the city in which the individual lived five years previously. Standard errors are corrected for intra-MSA correlation. 
Table 6: Effects of Segregation on Outcomes Using Natural Boundaries As Instruments

\begin{tabular}{|c|c|c|c|c|c|c|c|c|c|c|}
\hline \multirow[b]{2}{*}{$\begin{array}{l}\text { Independent } \\
\text { Variable } \\
\end{array}$} & \multicolumn{5}{|c|}{ Age $20-24$} & \multicolumn{5}{|c|}{ Age $25-30$} \\
\hline & $\begin{array}{c}\text { HS } \\
\text { Graduate }\end{array}$ & $\begin{array}{l}\text { College } \\
\text { Graduate }\end{array}$ & Idle & $\ln ($ Earn $)$ & $\begin{array}{l}\text { Social } \\
\text { Single } \\
\text { Mother }\end{array}$ & $\begin{array}{c}\text { HS } \\
\text { Graduate }\end{array}$ & $\begin{array}{l}\text { College } \\
\text { Graduate }\end{array}$ & Idle & $\ln ($ Earn $)$ & $\begin{array}{l}\text { Social } \\
\text { Single } \\
\text { Mothe }\end{array}$ \\
\hline \multicolumn{11}{|c|}{ A. Ordinary Least Squares Estimates } \\
\hline $\begin{array}{l}\text { Segregation * } \\
\text { Black }\end{array}$ & $\begin{array}{c}-.293 \\
(.043)\end{array}$ & $\begin{array}{l}-.057 \\
(.040)\end{array}$ & $\begin{array}{l}.335 \\
(.041)\end{array}$ & $\begin{array}{l}-.793 \\
(.153)\end{array}$ & $\begin{array}{l}.361 \\
(.058)\end{array}$ & $\begin{array}{l}-.212 \\
(.049)\end{array}$ & $\begin{array}{l}.000 \\
(.061)\end{array}$ & $\begin{array}{l}.291 \\
(.038)\end{array}$ & $\begin{array}{l}-.501 \\
(.113)\end{array}$ & $\begin{array}{l}.446 \\
(.059)\end{array}$ \\
\hline $\mathrm{N}$ & 90,684 & 90,684 & 90,684 & 52,281 & 45,442 & 129,324 & 129,324 & 129,324 & 97,973 & 66,276 \\
\hline $\mathrm{R}^{2}$ & .035 & .093 & .051 & .091 & .106 & .031 & .040 & .050 & .096 & .109 \\
\hline $\begin{array}{l}\text { Segregation * } \\
\text { Black }\end{array}$ & $\begin{array}{l}-.472 \\
(.059)\end{array}$ & $\begin{array}{l}-.096 \\
(.041)\end{array}$ & $\begin{array}{l}.378 \\
(.041)\end{array}$ & $\begin{array}{l}-1.124 \\
(.155)\end{array}$ & $\begin{array}{l}.198 \\
(.062)\end{array}$ & $\begin{array}{l}-.262 \\
(.053)\end{array}$ & $\begin{array}{l}-.071 \\
(.065)\end{array}$ & $\begin{array}{l}.556 \\
(.054)\end{array}$ & $\begin{array}{l}-.772 \\
(.122)\end{array}$ & $\begin{array}{l}.857 \\
(.099)\end{array}$ \\
\hline N & 90,684 & 90,684 & 90.684 & 52,281 & 45,442 & 129,324 & 129,324 & 129,324 & 97,973 & 66,276 \\
\hline $\mathrm{R}^{2}$ & .035 & .093 & .050 & .090 & .106 & .031 & .040 & .049 & .096 & .106 \\
\hline
\end{tabular}

Note: Regressions include the same set of controls as in Table 4. The instruments for segregation and segregation*black are quadratics in the number of inter- and intra-county rivers, and these terms interacted with black. Standard errors are corrected for intra-MSA correlation. 
Table 7: The Effect of Segregation on the Components of Earnings IV Estimates for Population Aged 25-30

\begin{tabular}{|c|c|c|c|c|c|}
\hline \multirow[b]{2}{*}{ Independent Variable } & \multicolumn{2}{|c|}{ Work and Earnings } & \multicolumn{3}{|c|}{ Components of Earnings } \\
\hline & Work & $\ln ($ Earn $)$ & $\ln ($ Weeks $)$ & $\ln$ (Hours/Week) & $\ln$ (Hourly Wage) \\
\hline Segregation & $\begin{array}{c}.001 \\
(.020)\end{array}$ & $\begin{array}{l}-.029 \\
(.066)\end{array}$ & $\begin{array}{c}.078 \\
(.028)\end{array}$ & $\begin{array}{l}-.103 \\
(.017)\end{array}$ & $\begin{array}{c}.004 \\
(.060)\end{array}$ \\
\hline Segregation * Black & $\begin{array}{l}-.306 \\
(.039)\end{array}$ & $\begin{array}{l}-.517 \\
(.118)\end{array}$ & $\begin{array}{l}-.430 \\
(.066)\end{array}$ & $\begin{array}{l}-.106 \\
(.035)\end{array}$ & $\begin{array}{l}-.029 \\
(.070)\end{array}$ \\
\hline Education Dummies & Yes & Yes & Yes & Yes & Yes \\
\hline Sample & Not in school & $\begin{array}{c}\text { Working, } \\
\text { Not in school }\end{array}$ & $\begin{array}{c}\text { Working, } \\
\text { Not in school }\end{array}$ & $\begin{array}{c}\text { Working, } \\
\text { Not in school }\end{array}$ & $\begin{array}{c}\text { Working, } \\
\text { Not in school }\end{array}$ \\
\hline $\mathrm{N}$ & 121,687 & 105,997 & 106,432 & 106,432 & 103,663 \\
\hline $\mathrm{R}^{2}$ & .113 & .170 & .043 & .068 & .152 \\
\hline
\end{tabular}

Note: All regressions include the same set of independent variables and instruments as in Table 4. Standard errors are corrected for intra-MSA correlation. 
Table 8: The Effects of Segregation on Central City and Non-Central City Residents

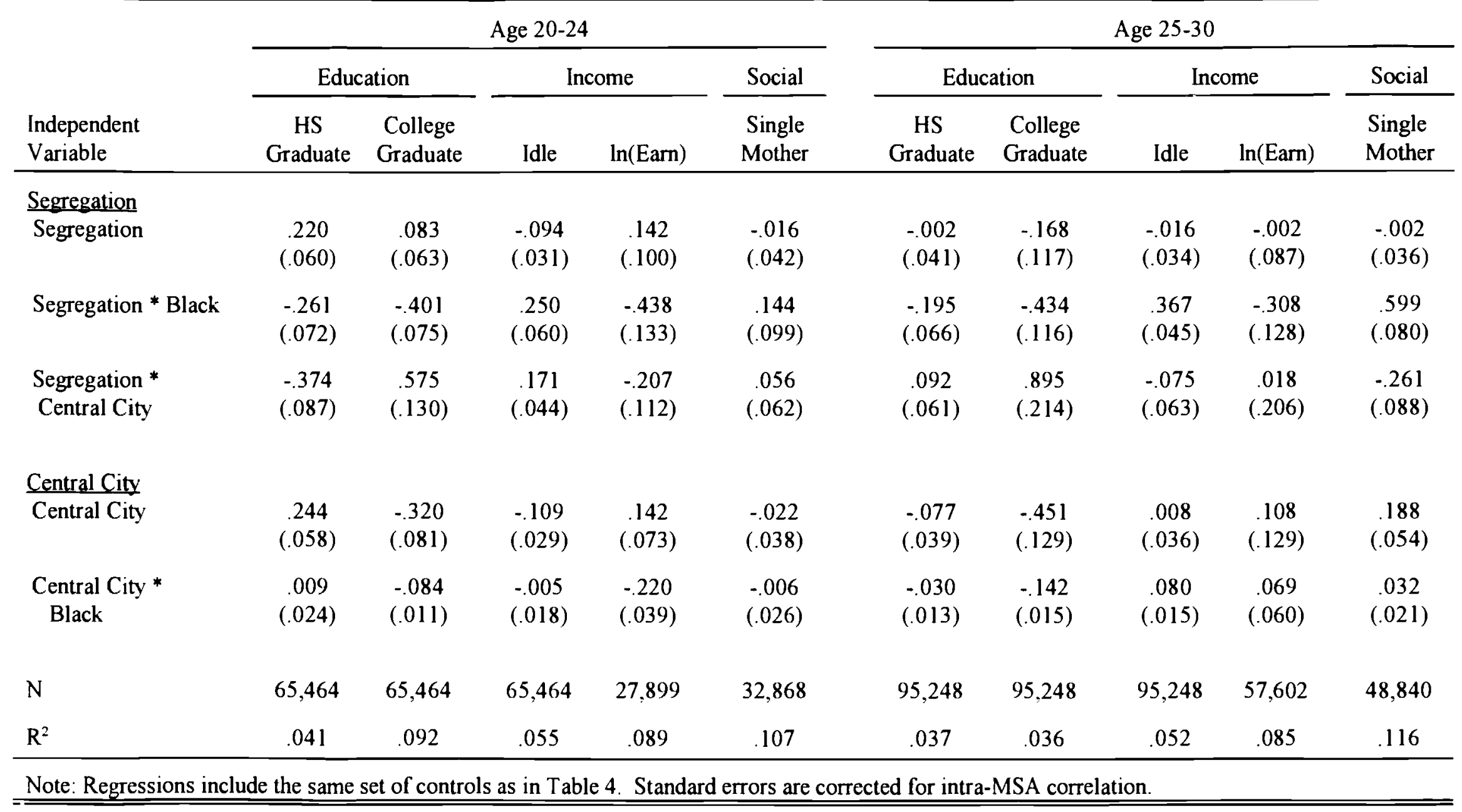


Table 9: Alternative Variables Explaining for Poor Outcomes

\begin{tabular}{|c|c|c|c|c|c|}
\hline Measure & Mean & $\begin{array}{l}\text { Standard } \\
\text { Deviation }\end{array}$ & Minimum & Maximum & \\
\hline Black Education Exposure & -.086 & .044 & -.206 & .082 & \\
\hline \multicolumn{6}{|l|}{$\begin{array}{l}\text { Parents Background } \\
\text { (Black-White) }\end{array}$} \\
\hline Single Mothers & .247 & .117 & -.165 & .587 & \\
\hline Males Education & -.173 & .106 & -.514 & .143 & \\
\hline \multirow[t]{3}{*}{$\begin{array}{l}\text { Time to Work (minutes) } \\
\text { (Black-White) }\end{array}$} & -.14 & 2.64 & -9.43 & 7.30 & \\
\hline & \multicolumn{3}{|c|}{ Correlation } & & \\
\hline & $\begin{array}{c}\text { Housing } \\
\text { Segregation } \\
\end{array}$ & $\begin{array}{l}\text { Education } \\
\text { Exposure }\end{array}$ & $\begin{array}{c}\text { Single } \\
\text { Mothers }\end{array}$ & $\begin{array}{c}\text { Males } \\
\text { Education }\end{array}$ & $\begin{array}{l}\text { Time to } \\
\text { Work }\end{array}$ \\
\hline Housing Segregation & 1.000 & & & & \\
\hline Education Exposure & -.443 & 1.000 & & & \\
\hline Single Mothers & .382 & -.217 & 1.000 & & \\
\hline Males Education & -.049 & .408 & -.228 & 1.000 & \\
\hline Time to Work & .081 & -.022 & -.031 & .081 & 1.000 \\
\hline
\end{tabular}


Table 10: Alternative Explanations for the Effect of Segregation on Outcomes OLS Estimates for Population Aged 25-30

\begin{tabular}{|c|c|c|c|c|c|}
\hline \multirow[b]{2}{*}{ Independent Variable } & \multicolumn{2}{|c|}{ Education } & \multicolumn{2}{|c|}{ Income } & \multirow{2}{*}{$\begin{array}{l}\text { Social } \\
\text { Single } \\
\text { Mother }\end{array}$} \\
\hline & $\begin{array}{c}\text { HS } \\
\text { Graduate }\end{array}$ & $\begin{array}{c}\text { College } \\
\text { Graduate }\end{array}$ & Idle & $\ln ($ Earn $)$ & \\
\hline \multicolumn{6}{|l|}{ Segregation } \\
\hline Housing Segregation & $\begin{array}{l}.002 \\
(.027)\end{array}$ & $\begin{array}{l}-.125 \\
(.066)\end{array}$ & $\begin{array}{c}.030 \\
(.021)\end{array}$ & $\begin{array}{l}-.167 \\
(.083)\end{array}$ & $\begin{array}{l}-.005 \\
(.028)\end{array}$ \\
\hline Housing Segregation * Black & $\begin{array}{l}-.140 \\
(.048)\end{array}$ & $\begin{array}{c}.041 \\
(.057)\end{array}$ & $\begin{array}{c}.214 \\
(.040)\end{array}$ & $\begin{array}{l}-.325 \\
(.133)\end{array}$ & $\begin{array}{c}.356 \\
(.073)\end{array}$ \\
\hline \multicolumn{6}{|l|}{ Education Spillovers } \\
\hline Education Exposure & $\begin{array}{l}.045 \\
(.088)\end{array}$ & $\begin{array}{l}-.285 \\
(.190)\end{array}$ & $\begin{array}{c}.107 \\
(.052)\end{array}$ & $\begin{array}{c}-.433 \\
(.226)\end{array}$ & $\begin{array}{c}.075 \\
(.083)\end{array}$ \\
\hline Education Exposure ${ }^{*}$ Black & $\begin{array}{c}.619 \\
(.199)\end{array}$ & $\begin{array}{c}.288 \\
(.185)\end{array}$ & $\begin{array}{l}-.106 \\
(.148)\end{array}$ & $\begin{array}{l}1.096 \\
(.422)\end{array}$ & $\begin{array}{l}-.526 \\
(.307)\end{array}$ \\
\hline \multicolumn{6}{|l|}{ Parents Background } \\
\hline Single Mothers & $\begin{array}{l}-.030 \\
(.036)\end{array}$ & $\begin{array}{c}-.032 \\
(.071)\end{array}$ & $\begin{array}{l}-.012 \\
(.023)\end{array}$ & $\begin{array}{c}.113 \\
(.104)\end{array}$ & $\begin{array}{c}.033 \\
(.034)\end{array}$ \\
\hline Single Mothers * Black & $\begin{array}{l}-.044 \\
(.088)\end{array}$ & $\begin{array}{c}.067 \\
(.074)\end{array}$ & $\begin{array}{c}.106 \\
(.061)\end{array}$ & $\begin{array}{l}-.193 \\
(.193)\end{array}$ & $\begin{array}{c}.139 \\
(.098)\end{array}$ \\
\hline Male Education & $\begin{array}{l}-.106 \\
(.038)\end{array}$ & $\begin{array}{l}-.372 \\
(.098)\end{array}$ & $\begin{array}{c}.090 \\
(.024)\end{array}$ & $\begin{array}{l}-.066 \\
(.082)\end{array}$ & $\begin{array}{c}.114 \\
(.033)\end{array}$ \\
\hline Male Education * Black & $\begin{array}{c}.071 \\
(.079)\end{array}$ & $\begin{array}{c}.281 \\
(.092)\end{array}$ & $\begin{array}{c}.025 \\
(.054)\end{array}$ & $\begin{array}{l}-.381 \\
(.185)\end{array}$ & $\begin{array}{l}-.073 \\
(.115)\end{array}$ \\
\hline \multicolumn{6}{|l|}{ Time To Work } \\
\hline$\overline{\text { Mean Time }}$ & $\begin{array}{c}.0012 \\
(.0013)\end{array}$ & $\begin{array}{c}.0019 \\
(.0027)\end{array}$ & $\begin{array}{c}-.0001 \\
(.0010)\end{array}$ & $\begin{array}{c}.0002 \\
(.0029)\end{array}$ & $\begin{array}{c}.0003 \\
(.0010)\end{array}$ \\
\hline Mean Time ${ }^{*}$ Black & $\begin{array}{l}-.0029 \\
(.0026)\end{array}$ & $\begin{array}{l}-.0020 \\
(.0024)\end{array}$ & $\begin{array}{c}.0056 \\
(.0019)\end{array}$ & $\begin{array}{l}-.0107 \\
(.0053)\end{array}$ & $\begin{array}{c}.0031 \\
(.0032)\end{array}$ \\
\hline $\mathrm{N}$ & 139,715 & 139,715 & 139,715 & 105,997 & 71,531 \\
\hline $\mathrm{R}^{2}$ & .032 & .044 & .051 & .096 & .110 \\
\hline $\begin{array}{l}\text { Reduction in Coefficient on } \\
\text { Segregation * Black }\end{array}$ & $37 \%$ & -- & $25 \%$ & $40 \%$ & $22 \%$ \\
\hline
\end{tabular}




\begin{tabular}{|c|c|c|c|c|c|}
\hline \multirow[b]{2}{*}{ MSA } & \multirow[b]{2}{*}{ Name } & \multirow[b]{2}{*}{$\begin{array}{c}\text { Housing } \\
\text { Segregation }\end{array}$} & \multirow[b]{2}{*}{$\begin{array}{l}\text { Education } \\
\text { Exposure }\end{array}$} & \multicolumn{2}{|c|}{ Fiscal Variables, 1962} \\
\hline & & & & $\begin{array}{l}\text { Number of } \\
\text { Governments }\end{array}$ & $\begin{array}{l}\text { Share of } \\
\text { Intergov } \\
\text { Revenue }\end{array}$ \\
\hline 80 & Akron, $\mathrm{OH}$ & .693 & -.083 & 60 & .258 \\
\hline 120 & Albany, GA & .623 & -.103 & 3 & .330 \\
\hline 160 & Albany-Schnectady-Troy, NY & .620 & -.078 & 117 & .261 \\
\hline 200 & Albuquerque, NM & .336 & -.034 & 2 & .494 \\
\hline 220 & Alexandria, VA & .571 & -.087 & 8 & .322 \\
\hline 240 & Allentown, PA & .534 & -.065 & 108 & .255 \\
\hline 360 & Anaheim, CA & .345 & -.069 & 23 & .293 \\
\hline 380 & Anchorage, $\mathrm{AK}$ & .333 & -.041 & $-\cdots$ & .317 \\
\hline 405 & Anderson, SC & .418 & -.059 & 10 & .407 \\
\hline 440 & Ann Arbor, MI & .499 & -.056 & 27 & .298 \\
\hline 450 & Anniston, $\mathrm{AL}$ & .501 & -.05 & 8 & .367 \\
\hline 480 & Asheville, NC & .626 & -.051 & 5 & .426 \\
\hline 500 & Athens, GA & .456 & -.032 & 24 & .33 \\
\hline 520 & Atlanta, GA & .673 & -.113 & 97 & .33 \\
\hline 560 & Atlantic City, NJ & .632 & -.071 & 39 & .143 \\
\hline 600 & Augusta, GA & .439 & -.074 & 15 & .33 \\
\hline 620 & Aurora-Elgin, IL & .512 & -.128 & 51 & .177 \\
\hline 640 & Austin, TX & .507 & -.135 & 16 & .247 \\
\hline 680 & Bakersfield, CA & .505 & -.080 & 9 & .293 \\
\hline 720 & Baltimore, MD & .709 & -.107 & 20 & .379 \\
\hline 760 & Baton Rouge, LA & .641 & -.083 & 14 & .452 \\
\hline 780 & Battle Creek, MI & .635 & -.084 & 28 & .298 \\
\hline 840 & Beaumont-Port Arthur, TX & .678 & -.077 & 16 & .247 \\
\hline 845 & Beaver County, PA & .621 & -.061 & 53 & .255 \\
\hline 870 & Benton Harbor, MI & .741 & -.128 & 39 & .298 \\
\hline 875 & Bergen-Passaic, NJ & .713 & -.138 & 86 & .143 \\
\hline 920 & Biloxi-Gulfport, MS & .462 & -.067 & 6 & .401 \\
\hline
\end{tabular}




\begin{tabular}{|c|c|c|c|c|c|}
\hline \multirow[b]{2}{*}{ MSA } & \multirow[b]{2}{*}{ Name } & \multirow[b]{2}{*}{$\begin{array}{c}\text { Housing } \\
\text { Segregation }\end{array}$} & \multirow[b]{2}{*}{$\begin{array}{l}\text { Education } \\
\text { Exposure }\end{array}$} & \multicolumn{2}{|c|}{ Fiscal Variables, 1962} \\
\hline & & & & $\begin{array}{c}\text { Number of } \\
\text { Governments }\end{array}$ & $\begin{array}{l}\text { Share of } \\
\text { Intergov. } \\
\text { Revenue }\end{array}$ \\
\hline 1000 & Birmingham, $\mathrm{AL}$ & .719 & -.07 & 61 & .367 \\
\hline 1120 & Boston, MA & .675 & -.129 & 76 & .230 \\
\hline 1140 & Bradenton, FL & .698 & -.153 & 6 & .215 \\
\hline 1145 & Brazoria, TX & .464 & -.048 & 14 & .247 \\
\hline 1160 & Bridgeport, CT & .675 & -.179 & 8 & .172 \\
\hline 1200 & Brockton, MA & .490 & -.079 & 10 & .230 \\
\hline 1260 & Bryan-College Station, TX & .438 & -.126 & 2 & .247 \\
\hline 1280 & Buffalo, NY & .807 & -.101 & 43 & .261 \\
\hline 1300 & Burlington, NC & .401 & -.083 & 4 & .426 \\
\hline 1320 & Canton, $\mathrm{OH}$ & .636 & -.131 & 55 & .258 \\
\hline 1400 & Champaign-Urbana, IL & .442 & -.066 & 51 & .177 \\
\hline 1440 & Charleston, SC & .480 & -.097 & 18 & .407 \\
\hline 1480 & Charleston, WV & .596 & .018 & 18 & .346 \\
\hline 1520 & Charlotte, NC & .537 & -.092 & 44 & .426 \\
\hline 1540 & Charlottesville, VA & .370 & -.067 & 4 & .322 \\
\hline 1560 & Chattanooga, TN & .724 & -.074 & 19 & .274 \\
\hline 1600 & Chicago, IL & .836 & -.118 & 221 & .177 \\
\hline 1640 & Cincinnati, $\mathrm{OH}$ & .761 & -.064 & 154 & .258 \\
\hline 1660 & Clarkesville, TN & .374 & -.002 & 5 & .274 \\
\hline 1680 & Cleveland, $\mathrm{OH}$ & .848 & -.112 & 134 & .258 \\
\hline 1720 & Colorado Springs, CO & .425 & -.056 & 8 & .309 \\
\hline 1760 & Columbia, SC & .531 & -.081 & 21 & .407 \\
\hline 1800 & Columbus, GA & .574 & -.072 & 5 & .33 \\
\hline 1840 & Columbus, $\mathrm{OH}$ & .672 & -.105 & 196 & .258 \\
\hline 1880 & Corpus Christi, TX & .448 & -.091 & 14 & .247 \\
\hline 1920 & Dallas, TX & .592 & -.148 & 84 & .247 \\
\hline 1950 & Danville, VA & .308 & -.032 & 3 & .322 \\
\hline
\end{tabular}




\begin{tabular}{|c|c|c|c|c|c|}
\hline \multirow[b]{2}{*}{ MSA } & \multirow[b]{2}{*}{ Name } & \multirow[b]{2}{*}{$\begin{array}{l}\text { Housing } \\
\text { Segregation }\end{array}$} & \multirow[b]{2}{*}{$\begin{array}{l}\text { Education } \\
\text { Exposure }\end{array}$} & \multicolumn{2}{|c|}{ Fiscal Variables, 1962} \\
\hline & & & & $\begin{array}{c}\text { Number of } \\
\text { Governments }\end{array}$ & $\begin{array}{l}\text { Share of } \\
\text { Intergov. } \\
\text { Revenue }\end{array}$ \\
\hline 1960 & Davenport, IA & .585 & -.072 & 89 & .211 \\
\hline 2000 & Dayton, $\mathrm{OH}$ & .751 & -.071 & 96 & .258 \\
\hline 2020 & Daytona Beach, FL & .691 & -.058 & 12 & .215 \\
\hline 2030 & Decatur, $\mathrm{AL}$ & .616 & -.078 & 10 & .367 \\
\hline 2040 & Decatur, IL & .584 & -.113 & 27 & .177 \\
\hline 2080 & Denver, $\mathrm{CO}$ & .64 & -.073 & 23 & .309 \\
\hline 2120 & Des Moines, IA & .662 & -.086 & 43 & .211 \\
\hline 2160 & Detroit, MI & .873 & -.098 & 233 & .298 \\
\hline 2180 & Dothan, AL & .411 & -.079 & 16 & .367 \\
\hline 2320 & El Paso, TX & .475 & .082 & 4 & .247 \\
\hline 2360 & Erie, PA & .636 & -.111 & 40 & .255 \\
\hline 2440 & Evansville, $\mathbb{I N}$ & .606 & -.063 & 42 & .250 \\
\hline 2560 & Fayetteville, NC & .304 & -.002 & 6 & .426 \\
\hline 2640 & Flint, MI & .809 & -.074 & 31 & .298 \\
\hline 2650 & Florence, AL & .442 & -.036 & 11 & .367 \\
\hline 2655 & Florence, SC & .464 & -.094 & 7 & .407 \\
\hline 2680 & Fort Lauderdale, FL & .678 & -.136 & 24 & .215 \\
\hline 2700 & Fort Myers, FL & .687 & -.108 & 1 & .215 \\
\hline 2710 & Fort Pierce, FL & .712 & -.177 & 6 & .215 \\
\hline 2750 & Fort Walton, FL & .382 & -.030 & 8 & .215 \\
\hline 2760 & Fort Wayne, IN & .742 & -.118 & 61 & .250 \\
\hline 2800 & Fort Worth, TX & .599 & -.120 & 44 & .247 \\
\hline 2840 & Fresno, CA & .469 & -.089 & 15 & .293 \\
\hline 2900 & Gainesville, FL & .387 & -.107 & 13 & .215 \\
\hline 2920 & Galveston, TX & .597 & -.117 & 5 & .247 \\
\hline 2960 & Gary, IN & .869 & -.063 & 48 & .250 \\
\hline 3000 & Grand Rapids, MI & .726 & -.061 & 57 & .298 \\
\hline
\end{tabular}




\begin{tabular}{|c|c|c|c|c|c|}
\hline \multirow[b]{2}{*}{ MSA } & \multirow[b]{2}{*}{ Name } & \multirow[b]{2}{*}{$\begin{array}{c}\text { Housing } \\
\text { Segregation }\end{array}$} & \multirow[b]{2}{*}{$\begin{array}{l}\text { Education } \\
\text { Exposure }\end{array}$} & \multicolumn{2}{|c|}{ Fiscal Variables, 1962} \\
\hline & & & & $\begin{array}{l}\text { Number of } \\
\text { Governments }\end{array}$ & $\begin{array}{l}\text { Share of } \\
\text { Intergov. } \\
\text { Revenue }\end{array}$ \\
\hline 3120 & Greensboro, NC & .611 & -.055 & 26 & .426 \\
\hline 3160 & Greenville, SC & .485 & -.075 & 29 & .407 \\
\hline 3200 & Hamilton, $\mathrm{OH}$ & .601 & -.086 & 24 & .258 \\
\hline 3240 & Harrisburg, PA & .759 & -.053 & 130 & .255 \\
\hline 3280 & Hartford, CT & .706 & -.190 & 22 & .172 \\
\hline 3290 & Hickory-Morganton, NC & .395 & -.007 & 13 & .426 \\
\hline 3320 & Honolulu, HI & .552 & .047 & 1 & .322 \\
\hline 3350 & Houma-Thibodaux, LA & .478 & -.005 & 4 & .452 \\
\hline 3360 & Houston, TX & .617 & -.112 & 40 & .247 \\
\hline 3440 & Huntsville, AL & .575 & -.075 & 4 & .367 \\
\hline 3480 & Indianapolis, $\mathbb{N}$ & .744 & -.062 & 158 & .250 \\
\hline 3520 & Jackson, MI & .698 & -.05 & 26 & .298 \\
\hline 3560 & Jackson, MS & .676 & -.1 & 17 & .401 \\
\hline 3600 & Jacksonville, FL & .583 & -.11 & 16 & .215 \\
\hline 3605 & Jacksonville, $\mathrm{NC}$ & .206 & .011 & 5 & .426 \\
\hline 3640 & Jersey City, NJ & .631 & -.019 & 12 & .143 \\
\hline 3690 & Joliet, IL & .689 & -.058 & 75 & .177 \\
\hline 3720 & Kalamazoo, MI & .528 & -.092 & 24 & .298 \\
\hline 3760 & Kansas City, MO & .721 & -.131 & 176 & .198 \\
\hline 3810 & Kileen-Temple, TX & .378 & .004 & 11 & .247 \\
\hline 3840 & Knoxville, TN & .617 & -.035 & 17 & .274 \\
\hline 3880 & Lafayette, LA & .496 & -.121 & 9 & .452 \\
\hline 3960 & Lake Charles, LA & .642 & -.084 & 6 & .452 \\
\hline 3965 & Lake County, IL & .689 & -.179 & 58 & .177 \\
\hline 3980 & Lakeland, FL & .568 & -.080 & 18 & .215 \\
\hline 4040 & Lansing, MI & .553 & .011 & 74 & .298 \\
\hline 4120 & Las Vegas, NV & .468 & -.098 & 4 & .3 \\
\hline
\end{tabular}


Appendix (continued)

\begin{tabular}{|c|c|c|c|c|c|}
\hline \multirow[b]{2}{*}{ MSA } & \multirow[b]{2}{*}{ Name } & \multirow[b]{2}{*}{$\begin{array}{l}\text { Housing } \\
\text { Segregation }\end{array}$} & \multirow[b]{2}{*}{$\begin{array}{l}\text { Education } \\
\text { Exposure }\end{array}$} & \multicolumn{2}{|c|}{ Fiscal Variables, 1962} \\
\hline & & & & $\begin{array}{c}\text { Number of } \\
\text { Governments }\end{array}$ & $\begin{array}{l}\text { Share of } \\
\text { Intergov. } \\
\text { Revenue }\end{array}$ \\
\hline 4200 & Lawton, OK & .329 & .008 & 9 & .330 \\
\hline 4280 & Lexington, KY & .539 & -.119 & 12 & .323 \\
\hline 4320 & Lima, $\mathrm{OH}$ & .658 & -.072 & 45 & .258 \\
\hline 4400 & Little Rock, AR & .605 & -.084 & 24 & .349 \\
\hline 4420 & Longview, TX & .464 & -.077 & 10 & .247 \\
\hline 4440 & Lorain-Elyria, $\mathrm{OH}$ & .554 & -.068 & 37 & .258 \\
\hline 4480 & Los Angeles, $\mathrm{CA}$ & .641 & -.090 & 72 & .293 \\
\hline 4520 & Louisville, KY & .694 & -.096 & 103 & .323 \\
\hline 4600 & Lubbock, TX & .544 & -.166 & 5 & .247 \\
\hline 4640 & Lynchburg, VA & .403 & -.079 & 4 & .322 \\
\hline 4680 & Macon-Warner, GA & .525 & -.103 & 9 & .330 \\
\hline 4720 & Madison, WI & .489 & .026 & 59 & .356 \\
\hline 4900 & Melbourne, FL & .523 & -.083 & 13 & .215 \\
\hline 4920 & Memphis, TN & .691 & -.130 & 22 & .274 \\
\hline 5000 & Miami, FL & .698 & -.102 & 27 & .215 \\
\hline 5015 & Middlesex, NJ & .523 & -.043 & 72 & .143 \\
\hline 5080 & Milwaukee, WI & .82 & -.158 & 89 & .356 \\
\hline 5120 & Minneapolis, $\mathrm{MN}$ & .612 & -.079 & 308 & .276 \\
\hline 5160 & Mobile, AL & .658 & -.087 & 18 & .367 \\
\hline 5190 & Monmouth, $\mathrm{NJ}$ & .658 & -.05 & 86 & .143 \\
\hline 5200 & Monroe, LA & .711 & -.121 & 5 & .452 \\
\hline 5240 & Montgomery, AL & .597 & -.099 & 7 & .367 \\
\hline 5320 & Muskegon, MI & .767 & -.102 & 26 & .298 \\
\hline 5360 & Nashville, TN & .604 & -.093 & 27 & .274 \\
\hline 5380 & Nassau-Suffolk County, NY & .743 & -.086 & 105 & .261 \\
\hline 5480 & New Haven, CT & .666 & -.098 & 10 & .172 \\
\hline 5520 & New London, CT & .496 & -.053 & 11 & .172 \\
\hline
\end{tabular}




\begin{tabular}{|c|c|c|c|c|c|}
\hline \multirow[b]{2}{*}{ MSA } & \multirow[b]{2}{*}{ Name } & \multirow[b]{2}{*}{$\begin{array}{c}\text { Housing } \\
\text { Segregation }\end{array}$} & \multirow[b]{2}{*}{$\begin{array}{l}\text { Education } \\
\text { Exposure }\end{array}$} & \multicolumn{2}{|c|}{ Fiscal Variables, 1962} \\
\hline & & & & $\begin{array}{c}\text { Number of } \\
\text { Governments }\end{array}$ & $\begin{array}{l}\text { Share of } \\
\text { Intergov. } \\
\text { Revenue }\end{array}$ \\
\hline 5560 & New Orleans, LA & .678 & -.097 & 14 & .452 \\
\hline 5600 & New York, NY & .690 & -.101 & 72 & .261 \\
\hline 5640 & Newark, NJ & .780 & -.137 & 106 & .143 \\
\hline 5700 & Niagara Falls, NY & .666 & -.092 & 20 & .261 \\
\hline 5720 & Norfolk, VA & .492 & -.094 & 9 & .322 \\
\hline 5760 & Norwalk, CT & .557 & -.206 & 3 & .172 \\
\hline 5775 & Oakland, CA & .616 & -.121 & 24 & .293 \\
\hline 5790 & Ocala, FL & .520 & -.042 & 5 & .215 \\
\hline 5880 & Oklahoma City, OK & .595 & -.065 & 58 & .330 \\
\hline 5920 & Omaha, NE & .706 & -.112 & 40 & .123 \\
\hline 5950 & Orange County, NY & .516 & -.081 & 39 & .261 \\
\hline 5960 & Orlando, FL & .595 & -.138 & 20 & .215 \\
\hline 6000 & Oxnard-Ventura, CA & .391 & -.076 & 6 & .293 \\
\hline 6015 & Panama City, FL & .547 & -.096 & 9 & .215 \\
\hline 6025 & Pascagoula, MS & .553 & -.049 & 3 & .401 \\
\hline 6080 & Pensacola, FL & .530 & -.101 & 5 & .215 \\
\hline 6120 & Peoria, IL & .701 & -.098 & 100 & .177 \\
\hline 6160 & Philadelphia, PA & .751 & -.118 & 339 & .255 \\
\hline 6200 & Phoenix, AZ & .444 & -.109 & 17 & .299 \\
\hline 6280 & Pittsburgh, PA & .713 & -.071 & 297 & .255 \\
\hline 6440 & Portland, OR & .673 & -.081 & 33 & .277 \\
\hline 6460 & Poughkeepsie, NY & .574 & -.139 & 30 & .261 \\
\hline 6480 & Providence, RI & .660 & -.111 & 32 & .218 \\
\hline 6600 & Racine, WI & .618 & -.083 & 18 & .356 \\
\hline 6640 & Raleigh, NC & .482 & -.113 & 20 & .426 \\
\hline 6760 & Richmond, VA & .589 & -.126 & 6 & .322 \\
\hline 6780 & Riverside-San Bernadino, CA & .390 & -.028 & 24 & .293 \\
\hline
\end{tabular}




\begin{tabular}{|c|c|c|c|c|c|}
\hline \multirow[b]{2}{*}{ MSA } & \multirow[b]{2}{*}{ Name } & \multirow[b]{2}{*}{$\begin{array}{c}\text { Housing } \\
\text { Segregation }\end{array}$} & \multirow[b]{2}{*}{$\begin{array}{c}\text { Education } \\
\text { Exposure }\end{array}$} & \multicolumn{2}{|c|}{ Fiscal Variables, 1962} \\
\hline & & & & $\begin{array}{c}\text { Number of } \\
\text { Governments }\end{array}$ & $\begin{array}{l}\text { Share of } \\
\text { Intergov. } \\
\text { Revenue }\end{array}$ \\
\hline 6800 & Roanoke, VA & .690 & -.132 & 6 & .322 \\
\hline 6840 & Rochester, NY & .663 & -.14 & 121 & .261 \\
\hline 6880 & Rockford, IL & .717 & -.147 & 35 & .177 \\
\hline 6920 & Sacramento, CA & .510 & -.072 & 14 & .293 \\
\hline 6960 & Saginaw, MI & .807 & -.137 & 70 & .298 \\
\hline 7040 & St. Louis, MO & .770 & -.097 & 271 & .198 \\
\hline 7120 & Salinas-Monterey, CA & .595 & -.002 & 11 & .293 \\
\hline 7160 & Salt Lake City, UT & .490 & -.067 & 35 & .329 \\
\hline 7240 & San Antonio, TX & .512 & -.024 & 19 & .247 \\
\hline 7320 & San Diego, CA & .503 & -.112 & 11 & .293 \\
\hline 7360 & San Francisco, CA & .577 & -.126 & 27 & .293 \\
\hline 7400 & San Jose, CA & .322 & -.060 & 16 & .293 \\
\hline 7480 & Santa Barbara, CA & .380 & -.014 & 4 & .293 \\
\hline 7510 & Sarasota, FL & .742 & -.164 & 3 & .215 \\
\hline 7520 & Savannah, GA & .614 & -.095 & 11 & .330 \\
\hline 7600 & Seattle, WA & .558 & -.065 & 46 & .329 \\
\hline 7680 & Shreveport, LA & .605 & -.124 & 8 & .452 \\
\hline 7800 & South Bend, IN & .646 & -.091 & 22 & .250 \\
\hline 7880 & Springfield, IL & .647 & -.134 & 57 & .177 \\
\hline 8000 & Springfield, MA & .658 & -.083 & 17 & .230 \\
\hline 8040 & Stamford, CT & .635 & -.201 & 4 & .172 \\
\hline 8120 & Stockton, CA & .498 & -.080 & 6 & .293 \\
\hline 8160 & Syracuse, NY & .732 & -.075 & 95 & .261 \\
\hline 8200 & Tacoma, WA & .454 & -.029 & 18 & .329 \\
\hline 8240 & Tallahassee, FL & .520 & -.124 & 6 & .215 \\
\hline 8280 & Tampa-St. Petersburg, FL & .687 & -.104 & 33 & .215 \\
\hline 8360 & Texarkarı, TX & .404 & -.044 & 10 & .247 \\
\hline
\end{tabular}




\begin{tabular}{|c|c|c|c|c|c|}
\hline \multirow[b]{2}{*}{ MSA } & \multirow[b]{2}{*}{ Name } & \multirow[b]{2}{*}{$\begin{array}{l}\text { Housing } \\
\text { Segregation }\end{array}$} & \multirow[b]{2}{*}{$\begin{array}{c}\text { Education } \\
\text { Exposure }\end{array}$} & \multicolumn{2}{|c|}{ Fiscal Variables, 1962} \\
\hline & & & & $\begin{array}{l}\text { Number of } \\
\text { Governments }\end{array}$ & $\begin{array}{l}\text { Share of } \\
\text { Intergov } \\
\text { Revenue }\end{array}$ \\
\hline 8400 & Toledo, $\mathrm{OH}$ & .736 & -.081 & 85 & .258 \\
\hline 8440 & Topeka, KS & .536 & -.093 & 16 & .228 \\
\hline 8480 & Trenton, NJ & .660 & -.147 & 13 & .143 \\
\hline 8520 & Tucson, AZ & .368 & -.049 & 2 & .299 \\
\hline 8560 & Tulsa, OK & .630 & -.081 & 45 & .330 \\
\hline 8600 & Tuscaloosa, AL & .503 & -.047 & 2 & .367 \\
\hline 8640 & Tyler, TX & .496 & -.108 & 7 & .247 \\
\hline 8680 & Utica-Rome, NY & .668 & -.077 & 77 & .261 \\
\hline 8720 & Vallejo-Napa, CA & .437 & -.024 & 10 & .293 \\
\hline 8760 & Vineland, $\mathrm{NJ}$ & .359 & -.038 & 14 & .143 \\
\hline 8800 & Waco, TX & .496 & -.103 & 13 & .247 \\
\hline 8840 & Washington, DC & .549 & -.107 & 73 & .251 \\
\hline 8880 & Waterbury, CT & .609 & -.125 & 9 & .172 \\
\hline 8960 & West Palm Beach, FL & .734 & -.192 & 37 & .215 \\
\hline 9040 & Wichita, KS & .629 & -.071 & 109 & .228 \\
\hline 9080 & Wichita Falls, TX & .593 & -.059 & 4 & .247 \\
\hline 9160 & Wilmington, DE & .545 & -.111 & 33 & .480 \\
\hline 9200 & Wilmington, $\mathrm{NC}$ & .582 & -.129 & 4 & .426 \\
\hline 9280 & York, PA & .71 & -.052 & 105 & .255 \\
\hline 9320 & Youngstown, $\mathrm{OH}$ & .749 & -.083 & 59 & .258 \\
\hline
\end{tabular}

